Portland State University

PDXScholar

\title{
Planning in Gateway and Natural Amenity Region Communities: Understanding the Unique Challenges Associated with Transportation, Mobility, and Livability
}

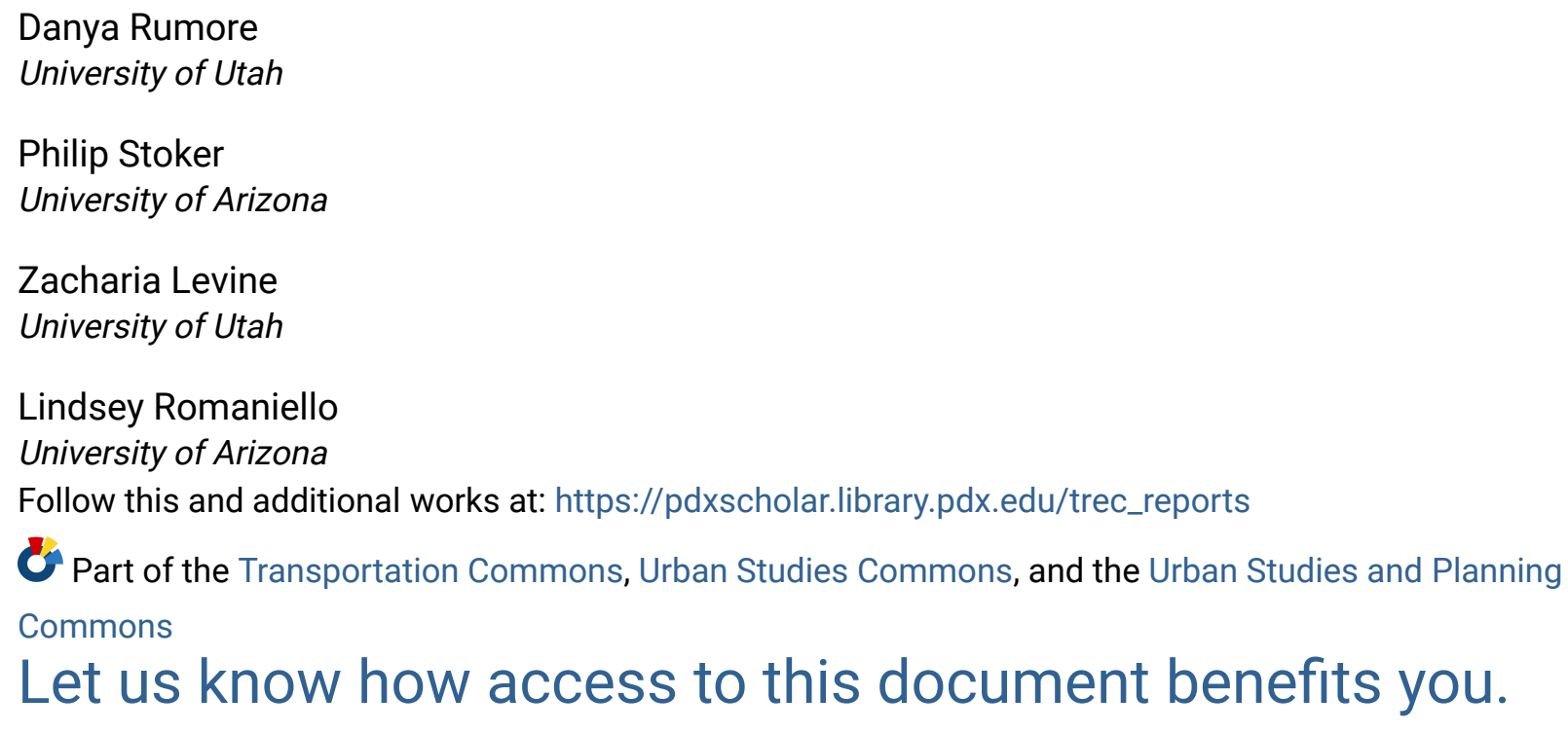
Amenity Region Communities: Understanding the Unique Challenges Associated with Transportation, Mobility, and Livability. NITC-RR-1118. Portland, OR: Transportation Research and Education Center (TREC), 2019. https://doi.org/10.15760/trec.230

This Report is brought to you for free and open access. It has been accepted for inclusion in TREC Final Reports by an authorized administrator of PDXScholar. Please contact us if we can make this document more accessible: pdxscholar@pdx.edu. 


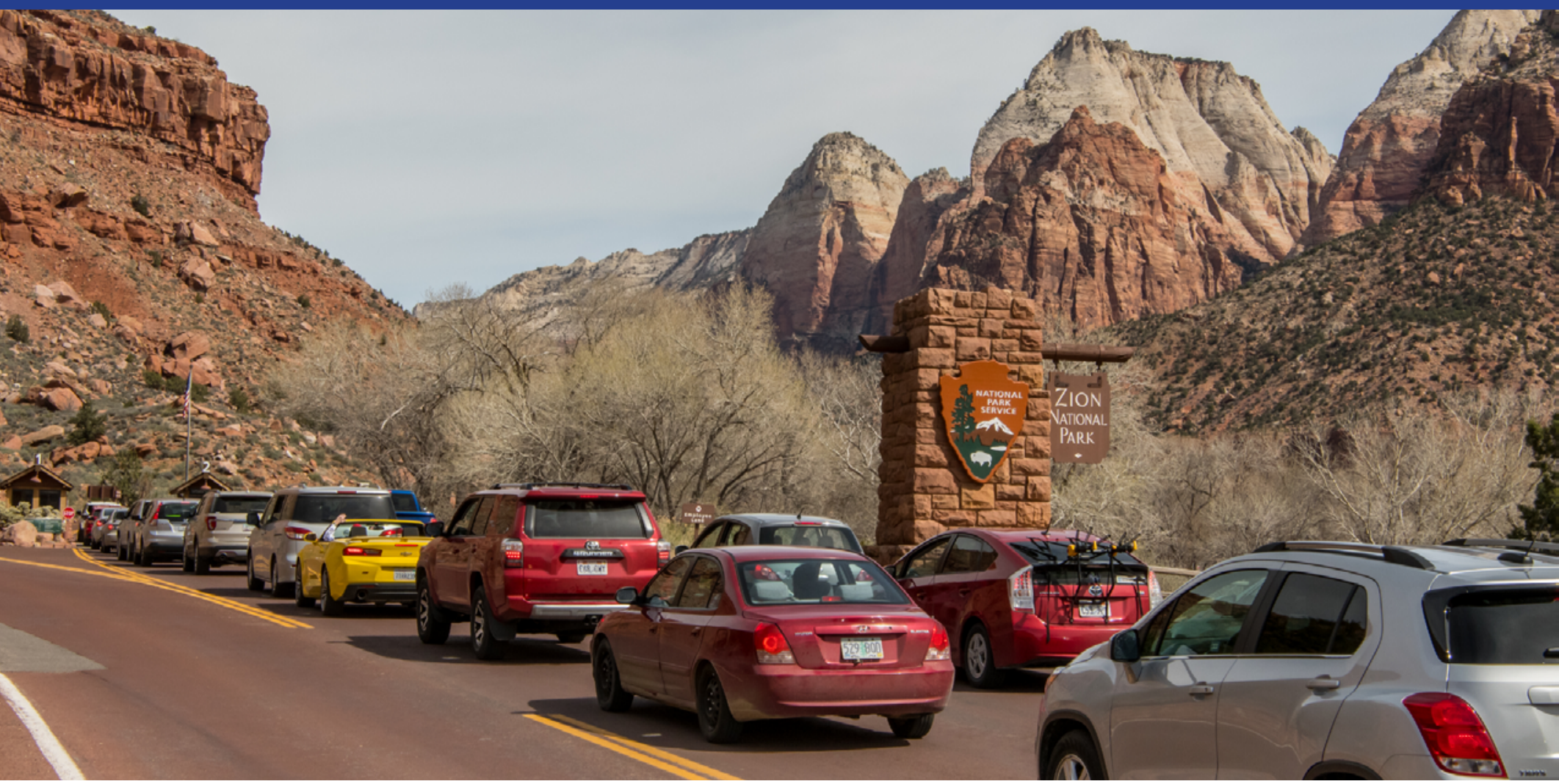

\section{Planning in Gateway and Natural Amenity Region Communities:}

Understanding the Unique Challenges Associated with Transportation, Mobility, and Livability

Danya Rumore, Ph.D.

Philip Stoker, Ph.D.

Zacharia Levine Lindsey Romaniello
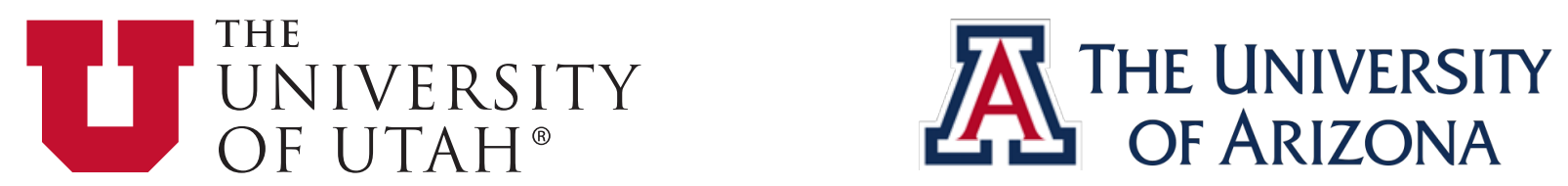


\title{
PLANNING IN GATEWAY AND NATURAL AMENITY REGION COMMUNITIES \\ UNDERSTANDING THE UNIQUE CHALLENGES ASSOCIATED WITH TRANSPORTATION, MOBILITY, AND LIVABILITY
}

\section{Final Report}

NITC-RR-1118

by

\author{
Danya Rumore \\ University of Utah \\ Philip Stoker \\ University of Arizona \\ Zacharia Levine \\ University of Utah \\ Lindsey Romaniello \\ University of Arizona \\ for
}

National Institute for Transportation and Communities (NITC)

P.O. Box 751

Portland, OR 97207
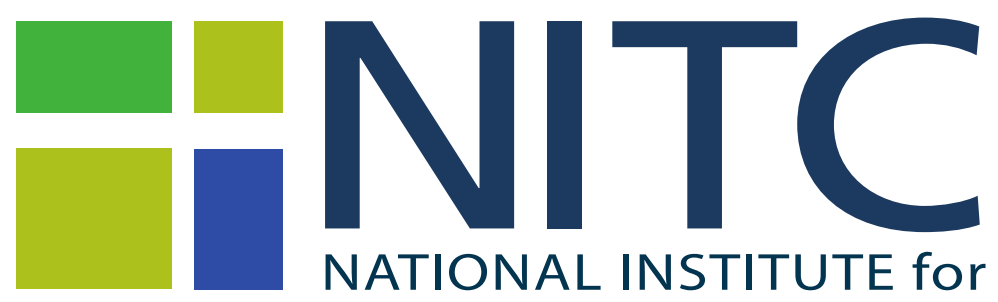

TRANSPORTATION and COMMUNITIES

June 2019 


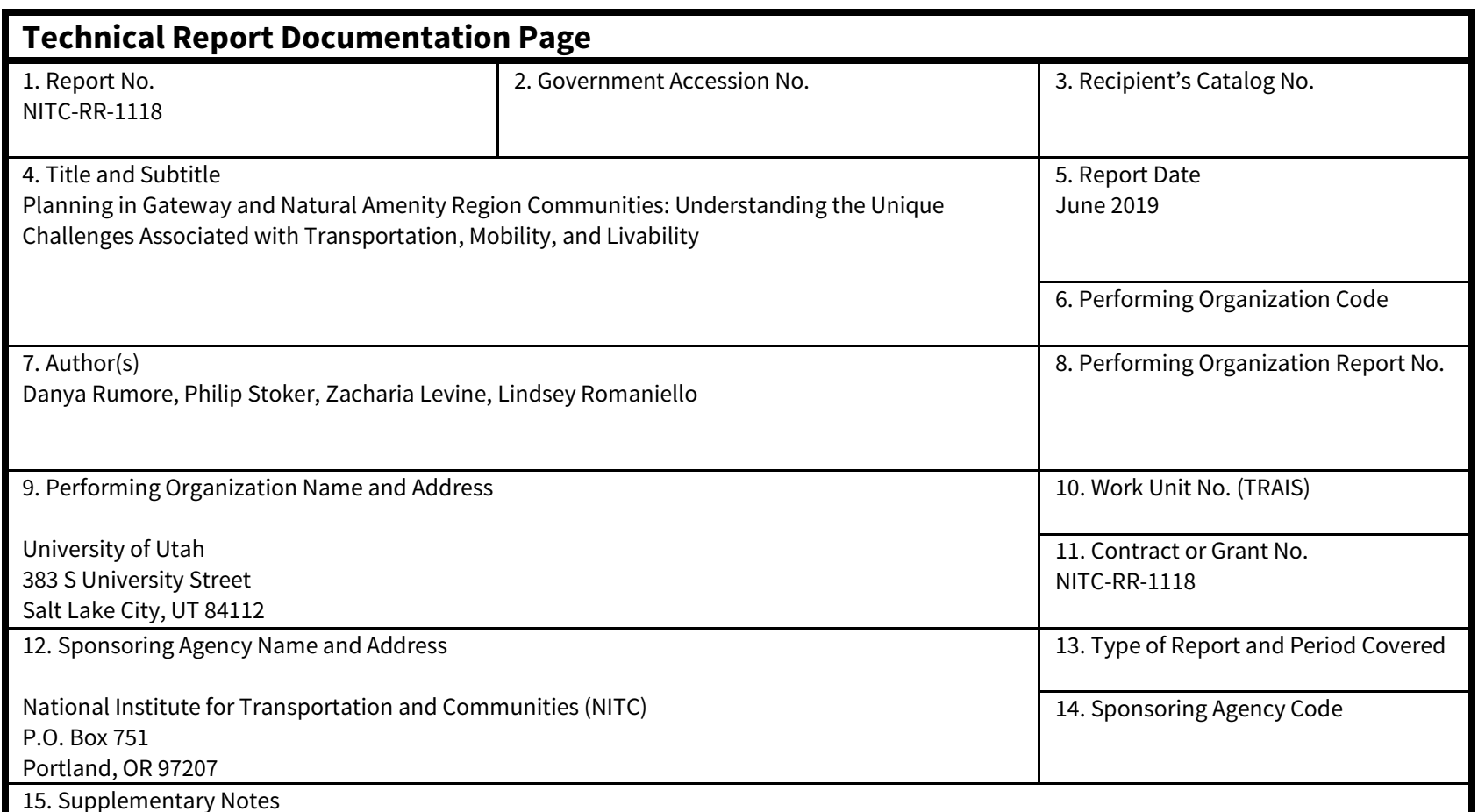

15. Supplementary Notes

16. Abstract

Communities outside of major public lands and other natural amenities throughout the western United States face a variety of transportation and planning-related concerns associated with rapid growth and increases in tourism. Surprisingly, while the unique transportation and planning-related challenges of these western gateway and amenity region (GNAR) communities have, to some extent, been documented in recreation and tourism research, these concerns have largely been overlooked in planning scholarship. To begin to address this gap, this report presents key descriptive findings from a study aimed at examining the unique transportation, mobility, and access to opportunity-related challenges being experienced by GNAR communities throughout the western U.S. It draws on findings from indepth interviews with 31 planners and other key public officials from 25 western GNAR communities, an online survey of planners and other key public officials in GNAR communities throughout the west, and observation of planning efforts in the regions around Zion National Park and Moab, UT, and Sandpoint, ID. Our results provide empirical evidence that many western GNAR communities are experiencing significant increases in growth and visitation pressures along with a number of related "big-city" problems, such as lack of affordable housing, income inequality, and transportation issues. These changes contrast against the fact that these communities value their small town character and related community characteristics. Our data suggest that despite these pressures, most GNAR communities are experiencing improved quality of life and visitor experience. However, some communities report declining quality of life and visitor experience, as well as extreme challenges associated with housing, transportation, and other planning concerns, raising the question of whether GNAR communities reach a tipping point at which visitation and development pressures result in overall impacts on community wellbeing. Our results also show that GNAR communities throughout the west are experimenting with innovative and promising approaches for tackling their housing and transportation issues. Further analysis is needed to better understand what kinds of GNAR communities are experiencing what kinds of challenges, as well as to assess the effectiveness of different kinds of strategies for addressing these challenges; we will explore those topics in future publications. One key takeaway from this study is that housing, transportation, and land use decisions are highly interwoven in GNAR communities throughout the west; further research is needed to better understand this connectivity and what it means for appropriate housing and access solutions.

$$
\text { 17. Key Words }
$$

\section{Distribution Statement} No restrictions. Copies available from NITC: www.nitc-utc.net

19. Security Classification (of this report)

Unclassified

20. Security Classification (of this page)
Unclassified

21. No. of Pages 67
22. Price 


\section{ACKNOWLEDGEMENTS}

We would like to thank the numerous funders and partners who have made this research and work possible. This project was predominantly funded by the National Institute for Transportation and Communities (NITC; grant number 1118), a U.S. DOT University Transportation Center. Additional funding and partnership were provided by the Town of Springdale, UT; Washington County, UT; the State of Utah Office of Tourism; Project 7B in Bonner County, ID; the University of Utah City and Metropolitan Planning Department and Environmental Dispute Resolution Program; and the University of Arizona College of Architecture, Planning, and Landscape Architecture. We would also like to thank the many representatives from western gateway and natural amenity regions who took the time to share their thoughts and ideas with us via interviews and our online survey. Cover photo by kellyvandellen (iStockphoto.com).

\section{DISCLAIMER}

The contents of this report reflect the views of the authors, who are solely responsible for the facts and the accuracy of the material and information presented herein. This document is disseminated under the sponsorship of the U.S. Department of Transportation University Transportation Centers Program in the interest of information exchange. The U.S. Government assumes no liability for the contents or use thereof. The contents do not necessarily reflect the official views of the U.S. Government. This report does not constitute a standard, specification, or regulation.

\section{RECOMMENDED CITATION}

Rumore, Danya, Philip Stoker, Zacharia Levine, and Lindsey Romaniello. Planning in Gateway and Natural Amenity Region Communities: Understanding the Unique Challenges Associated with Transportation, Mobility, and Livability. NITC-RR-1118. Portland, OR: Transportation Research and Education Center (TREC), 2019. 


\section{TABLE OF CONTENTS}

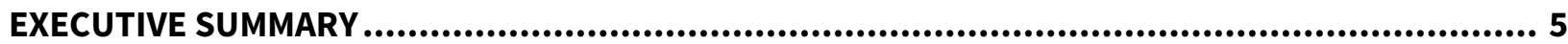

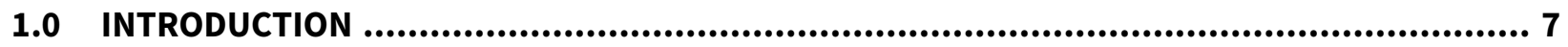

2.0 LITERATURE REVIEW ................................................................................... 8

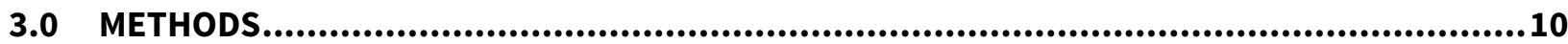

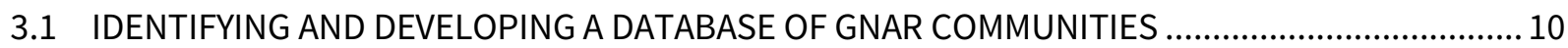

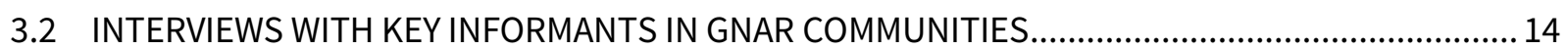

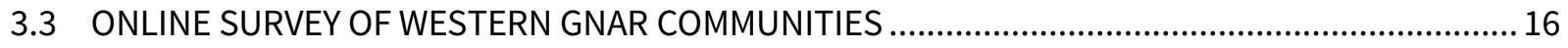

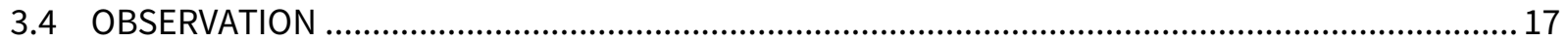

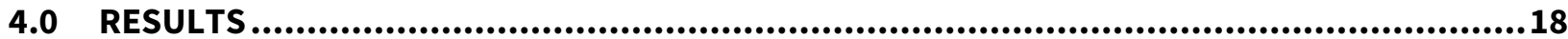

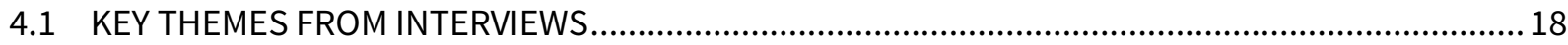

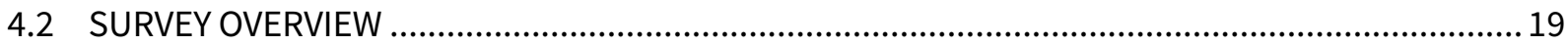

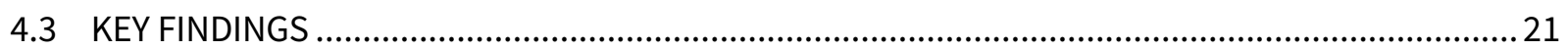

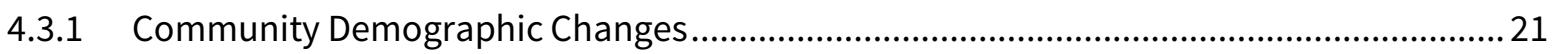

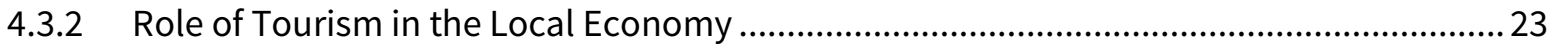

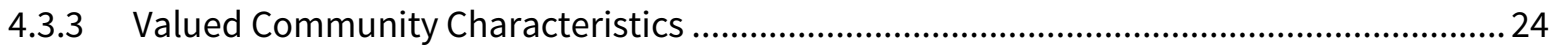

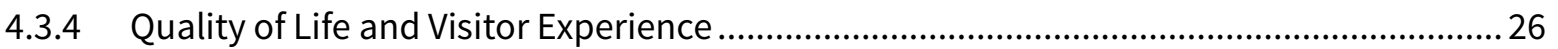

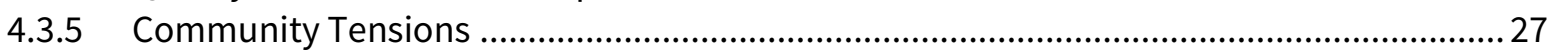

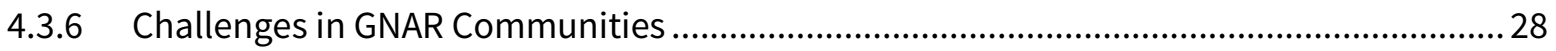

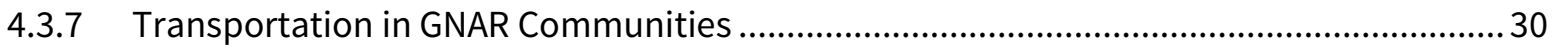

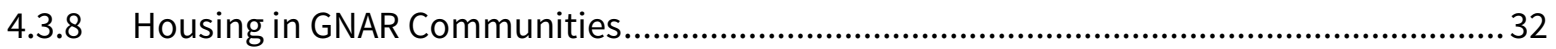

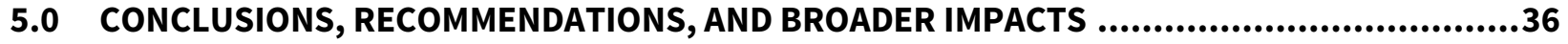

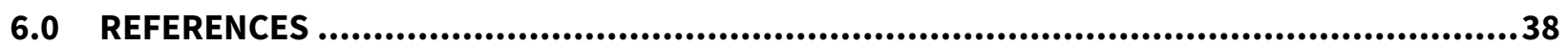

\section{APPENDICES}

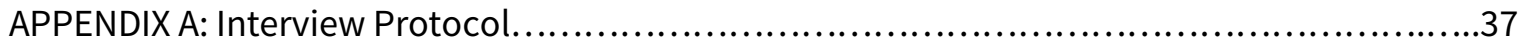

APPENDIX B: Interview Coding Key.................................................41

APPENDIX C: Questionnaire Used for Online Survey.....................................45

APPENDIX D: “Other” Problems Reported by Questionnaire Respondents....................63

\section{LIST OF TABLES}

Table 3.1 Basic selection method used to identify GNAR communities in the western U.S. $\quad 11$

Table 3.2 Communities and organizations represented by interviewees 14

Table 4.1 Survey sample characteristics $\quad 20$

Table 4.2 Which of the following best describes your position with the town/city you work for? 21

Table 4.3 Over the last 10 years, how have the year-round residents, part-time residents, and tourists changed? 
Table 4.4 Role of tourism and natural resource industries (like mining, forestry and energy development) in local economy

Table 4.6. Do you believe your community is doing enough to address housing challenges? 34

Table 4.7 What percentage of housing units in your community are occupied by year-round residents?

Table 4.8 Housing strategies employed by communities, according to respondents

\section{LIST OF FIGURES}

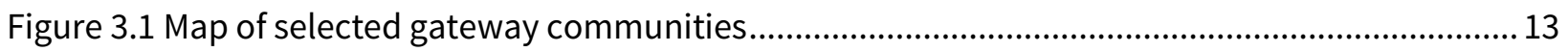

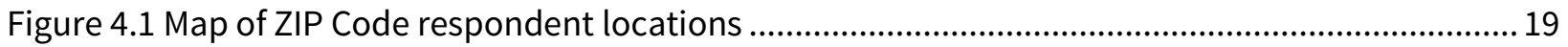

Figure 4.2 What percentage of residents in your community live there year-round? ............................ 22

Figure 4.3 Over the last 10 years how have the year-round residents, part-time residents, and tourist

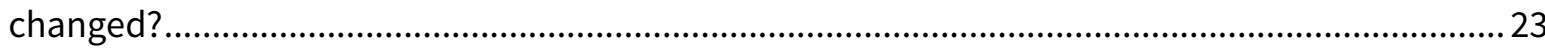

Figure 4.4 For the following community characteristics, please indicate whether they seem important for the entire community, important for more than half of the community, important for less than half the community or not important. 25

Figure 4.5 To what extent do you think the quality of life for year-round residents, part-time/seasonal residents, and tourists has gotten better or worst over the last 10 years?

Figure 4.6 To what extent does your community have tensions between long-term residents and recent residents? To what extent does your community have tensions between residents and tourists?

Figure 4.7 To what extent are the following challenges problematic in your community?...................29

Figure 4.8 In general, how easy or hard is it to travel around your community? .................................. 31

Figure 4.9 How satisfied are residents/tourists with the transportation options available in your community?

Figure 4.10 Transportation options in gateway communities: Which of the following transportation options exist in your community? (select all that apply) 


\section{EXECUTIVE SUMMARY}

Small rural cities and towns outside of significant natural amenities such as national parks, public lands, ski areas, and scenic rivers throughout the western United States and nationally face a variety of concerns associated with rapid growth and increases in tourism. These challenges range from congestion and overwhelmed transportation systems to lack of affordable housing and negative impacts on community character. Surprisingly, while the unique transportation and planning-related challenges of western gateway and natural amenity region (GNAR) communities have, to some extent, been noted in recreation and tourism research, these concerns are largely overlooked in planning scholarship.

This report shares high-level findings from a study aimed at addressing this gap through examining the unique transportation, mobility, and access to opportunity-related challenges being experienced by GNAR communities throughout the western U.S. The study involved a multipronged approach, which included: identification and development of a database of western GNAR communities; indepth interviews with 33 planners and other key public officials from 25 western gateway and amenity communities; on online survey of planners and other key public officials in gateway and amenity communities throughout the west; and observation of the Zion National Park and Moab regions of Utah and the Sandpoint region of Idaho. In this report, we provide a summary of key descriptive results from this study as well as identify pathways for future research. Results from additional analysis of our data will be provided in future publications.

The data collected through this study provide evidence to support our hypotheses that many western GNAR communities are growing, sometimes rapidly, and/or experiencing significant, sometimes dramatic, increases in visitation. As a result, GNAR communities throughout the west are experiencing a wide range of "big-city issues" despite being small towns. Prominent among these challenges are housing affordability, average wages relative to cost of living, lack of resources and revenue, and income inequality. These challenges stand out in stark contrast to the fact these places value and identify strongly with their small-town character.

Our results also show that GNAR communities often experience unique political and cultural tensions, such as those between "newcomers" and "oldtimers" and between tourists and residents. That said, these tensions seem to be much less pervasive than we hypothesized.

Our findings suggest that, despite the challenges these communities face, quality of life and quality of visitor experience in many GNAR communities seems to have improved over the last decade. That said, some communities report declining quality of life and/or visitor experience, raising questions about the source of this negative impact.

Based on our observation and work in GNAR communities, we suspect that once GNAR communities reach a certain level of development and visitation pressure, concerns about quality of life and visitor experience, as well as tensions within the community, tend to emerge. Much the same, we hypothesize that many of these issues become more pressing and development and/or visitation pressures increase. Further analyses of our data will provide insight into whether this is the case, as well as generally explore what kinds of GNAR communities are experiencing certain kinds of and 
intensity of planning and transportation issues. The results of additional analysis will be presented in future academic publications.

Regardless, it is clear that access to housing is a key issue across western GNAR communities. It is also evident that housing intersects in important ways with transportation and land use planning in GNAR communities, as it does in larger urban areas. We recommend that future research further explore the relationship between housing, transportation, and land use in GNAR communities, with a keen eye toward potential solutions and strategies for improving access to housing and transportation. Fortunately, our data suggest that many GNAR communities are experimenting with innovative and promising solutions for addressing their housing and transportation concerns, and we believe much can be learned from these efforts that can assist other communities - whether rural or urban -in making progress on these interconnected issues. 


\subsection{INTRODUCTION}

Small rural cities and towns outside of significant natural amenities such as national parks, public lands, ski areas, and scenic rivers throughout the western United States are becoming increasingly popular places to visit and live. As a result, many of these gateway and natural amenity region (GNAR) communities are grappling with a variety of unique transportation and planning-related challenges, which present major concerns for mobility, access to opportunity, and livability.

While these issues are obvious to those affected and are gaining increasing attention from popular press, they have previously received surprisingly little attention from planning scholars. Although existing studies provide some insight into the kinds of transportation and planning-related challenges experienced by parks, protected areas, recreational hot spots, and the communities around them, there is a significant need to broaden the scope of research on transportation and planning-related concerns across western GNAR communities, particularly to focus on the needs of both tourists and residents. Much the same, there is an opportunity to learn from and share the experiences of GNAR communities that have taken action to address their transportation and planning-related concerns.

This report begins to fill these gaps by documenting the transportation and planning-related concerns being experienced by gateway and amenity communities throughout the western U.S. It also examines what is being done to address key concerns. It does so through sharing high-level findings from a multipronged study involving 33 in-depth interviews with planners and other key public officials from 25 western gateway and amenity communities; on online survey of 333 planners and other key public officials in 263 gateway and amenity communities throughout the west; and ongoing observation of the Zion National Park and Moab regions of Utah and the Sandpoint region of Idaho.

This report specifically addresses the following questions:

- What defines a GNAR community, and what western communities fit the GNAR typology?

- What key planning, transportation, and livability challenges do western GNAR communities face?

- How generalizable and widespread are these concerns among western GNAR communities?

- What are western GNAR communities doing to address these challenges, and to what effect, specifically around transportation and other key planning concerns?

This report details the rationale for this research, our research methods, and results. It concludes by discussing the implications of our findings, the broader impacts of this research, and next steps for research and practice. Additional analysis of the data collected through this study will be provided in future publications. The overall goal of this research is to begin to assist GNAR communities in improving the mobility of people and goods and building strong communities amid the unique challenges they face. 


\subsection{LITERATURE REVIEW}

GNAR communities throughout the western United States and nationally face a variety of unique transportation and planning-related challenges, which present major concerns for mobility, access to opportunity, and livability. For example, the towns of Springdale and Rockville outside of Zion National Park have experienced severe congestion and parking issues associated with exponential increases in national park visitation. Jackson Hole, WY, (outside of Yellowstone National Park) and Moab, UT, (which is near Arches and Canyonlands national parks) struggle with similar issues. In Bonner County, ID, planners in the small resort town of Sandpoint have expressed concern that the town will "become a parking lot" if public transit and non-motorized transportation options for moving residents and visitors around aren't developed. In Tahoe, CA, neighborhoods are seeing increasing visitor traffic as Google Maps and other mapping services reroute drivers off of busy main corridors through community streets. In all of these areas, transportation issues are affecting the mobility of visitors and residents; the ability of employees to access work sites; public safety; environmental quality; and the general livability of communities. Transportation and mobility issues in such GNAR communities are also tied to other concerns, such as the siting of camping and recreation opportunities, and are interconnected with other planning and sustainability challenges, such as the affordability of living, economic development, air quality, livability, and equity.

While these issues are obvious to those affected and are gaining increasing attention from popular press (e.g., O'Donoghue, 2016), they have received surprisingly little attention from planning scholars. What research exists largely focuses on transportation issues within specific national parks (Daigle and Zimmerman, 2004; Hallo and Manning, 2009; Mace et al., 2013; Mace, 2014). The research that looks at gateway and amenity communities themselves tends to focus on specific concerns in individual municipalities - for example Vyas' 2008 study of trail development in the Town of Springdale.

Research has also tended to focus on engineering and technological risk factors and solutions, mainly related to traffic safety (Wang, Veneziano, Russell, and Al-Kaisy, 2016); throughput capacity (Dunning, 2005); transit and shuttle services (Daigle and Zimmerman, 2004; Mace, 2014); and the broad category of intelligent transportation systems (Dilworth, 2003). Existing research also tends to concentrate on visitors as the predominant transportation users, with studies examining visitor perceptions of congestion (Dilworth, 2003); visitor perceptions and adoption of alternative transportation options (White, 2007; Mace et al., 2013); and transportation-related impacts on visitor experience (Daigle, 2008).

Although existing studies provide some insight into the kinds of challenges experienced by parks, protected areas, recreational hot spots, and the communities around them, there is a significant need to broaden the scope of research on transportation and planning-related concerns across western GNAR communities. Further research is needed to examine the relationships between transportation infrastructure, mobility, accessibility, equity, and livability within communities surrounding tourism areas, with a keen focus on the needs of both tourists and residents.

Much the same, there is an opportunity to learn from and share the experiences of western GNAR communities that have taken action to address their transportation and planning-related concerns. 
Further, we know from our work with such communities that there is considerable opportunity to help public officials in these areas through capacity building and planning support. That said, research is needed to better understand the needs of these communities and the public officials working in them.

This report begins to address gaps in the literature by documenting the transportation and planningrelated concerns being experienced by gateway and amenity communities throughout the western U.S. It also examines what GNAR communities are doing to address theses key planning and transportation concerns. 


\subsection{METHODS}

As noted above, this report specifically addresses the following questions:

1. What defines a GNAR community, and what western communities fit the GNAR typology?

2. What key planning, transportation, and livability challenges do western GNAR communities face?

3. How generalizable and widespread are these concerns among western GNAR communities?

4. What are western GNAR communities doing to address these challenges, and to what effect, specifically around transportation and other key planning concerns?

To do so, this study employs a multipronged approach, involving: identification and development of a database of western GNAR communities; in-depth interviews with key informants in western gateway and amenity communities; a broader survey of planners, transportation professionals, and public officials in western gateway and amenity communities; and case studies of two gateway and amenity communities that are actively working to address their transportation and planning-related concerns. These methods are each described in full below.

\subsection{IDENTIFYING AND DEVELOPING A DATABASE OF GNAR COMMUNITIES}

Prior research has not clearly nor consistently defined GNAR communities, nor has it identified GNAR communities in the west. Therefore, a first necessary task for our study was to identify all small, rural communities that are proximate to national parks or other major natural amenities in our region of interest, which we defined for the purposes of this study as being in the United States between the west side of the Sierra Nevada Mountains and the east side of the Rocky Mountains. ${ }^{1}$

Drawing on existing literature, as well as personal observation, on-the-ground work with western GNAR communities, and consultation with scholars in rural sociology, rural planning, leisure and tourism studies, and geography, we established the following criteria for GNAR communities:

- Population of 150-25,000 people

- Further than 15 miles from a census designated urbanized area, by road

- Within 10 linear miles from the boundary of a national park, national monument, national forest, state park, wild and scenic river or other major river, or lake

We used multicriteria decision analysis using geospatial data to identify all communities in our region of interest that possess these characteristics. Table 3.1 outlines the sequential selection steps followed and provides a rationale for each of the above-listed GNAR community criteria used for this study.

This process identified 1,522 communities that fit our criteria. A map of identified GNAR communities is shown in Figure 3.1

\footnotetext{
${ }^{1}$ Coastal communities are excluded from the sample set because they are considered to have fundamentally different tourism-related economies and land management policies than interior communities.
} 
Table 3.1 Basic selection method used to identify GNAR communities in the western U.S.

\begin{tabular}{|c|c|c|c|}
\hline Analytical step & Data (source) & $\begin{array}{l}\text { Number of } \\
\text { communities } \\
\text { selected }\end{array}$ & Analytical rationale \\
\hline $\begin{array}{l}\text { Select by } \\
\text { polygon cities } \\
\text { and census } \\
\text { designated places } \\
\text { (CDPs) within } \\
\text { region of interest. }\end{array}$ & $\begin{array}{l}\text { USA Cities } \\
\text { (ESRI) }\end{array}$ & $\begin{array}{l}4,966 \\
\text { communities } \\
\text { selected from } \\
38,186 \\
\text { nationwide }\end{array}$ & $\begin{array}{l}\text { This study focuses on the development } \\
\text { trajectories and planning issues in GNAR } \\
\text { communities throughout the western } \\
\text { U.S. Only incorporated municipalities } \\
\text { and CDPs are included as these } \\
\text { designations indicate a minimum level } \\
\text { of local government organization and } \\
\text { civic structure. }\end{array}$ \\
\hline $\begin{array}{l}\text { Select by } \\
\text { attribute cities } \\
\text { and CDPs with } \\
\text { populations } \\
\text { between } 150 \text { and } \\
25,000 \text { residents }\end{array}$ & $\begin{array}{l}\text { USA Cities } \\
\text { (ESRI) }\end{array}$ & $\begin{array}{l}2,492 \\
\text { communities }\end{array}$ & $\begin{array}{l}\text { GNAR communities have smaller } \\
\text { population sizes. They tend to exhibit } \\
\text { less economic diversity and } \\
\text { connectedness with urbanized areas. } \\
\text { The final population range results from } \\
\text { an iterative process of setting thresholds } \\
\text { and evaluating communities added or } \\
\text { dropped on the extremes. On the lower } \\
\text { end of the population range, we want to } \\
\text { ensure selected communities have } \\
\text { enough full-time population to support } \\
\text { formal government entities, } \\
\text { policymaking bodies, public services, } \\
\text { and civic activities. On the higher end of } \\
\text { the spectrum, we want to include well- } \\
\text { reputed GNAR communities while } \\
\text { excluding places that are more akin to } \\
\text { economically diverse and } \\
\text { interconnected urbanized areas. }\end{array}$ \\
\hline $\begin{array}{l}\text { Select by } \\
\text { attribute } \\
\text { cities and CDPs } \\
\text { within } 10 \text { linear } \\
\text { miles of a } \\
\text { prominent natural } \\
\text { amenity }\end{array}$ & $\begin{array}{l}\text { National Parks, } \\
\text { National } \\
\text { Forests, State } \\
\text { Parks, Federal } \\
\text { Lands, Wild } \\
\text { and Scenic } \\
\text { Rivers, Major } \\
\text { Rivers, Lakes, } \\
\text { Rivers (ESRI) } \\
\end{array}$ & $\begin{array}{l}2,063 \\
\text { communities }\end{array}$ & $\begin{array}{l}\text { GNAR communities are proximal to } \\
\text { prominent natural amenities that } \\
\text { support tourism, outdoor recreation, } \\
\text { and extractive industries. Ten linear } \\
\text { miles was selected as the distance } \\
\text { threshold to emphasize that we are } \\
\text { interested in communities that serve as } \\
\text { gateways to the natural amenities of } \\
\text { interest. }\end{array}$ \\
\hline $\begin{array}{l}\text { Select by closest } \\
\text { facility cities and } \\
\text { CDPs located }\end{array}$ & $\begin{array}{l}\text { Major Roads } \\
\text { (ESRI) }\end{array}$ & $\begin{array}{l}1,522 \\
\text { communities }\end{array}$ & $\begin{array}{l}\text { GNAR communities are relatively } \\
\text { isolated from urbanized and } \\
\text { metropolitan statistical areas. As with }\end{array}$ \\
\hline
\end{tabular}




\begin{tabular}{l|l|l}
\hline $\begin{array}{l}\text { further than 15 } \\
\text { road miles from } \\
\text { urbanized area, as } \\
\text { defined by the } \\
\text { Census }\end{array}$ & $\begin{array}{l}\text { the population range, the distance } \\
\text { threshold results from an iterative } \\
\text { process of setting different thresholds } \\
\text { and evaluating communities added or } \\
\text { dropped from the selection set. In order } \\
\end{array}$ & $\begin{array}{l}\text { to select communities based on road } \\
\text { network distances, we used the Network } \\
\text { Analyst toolbox in ArcMap 10.4.1. }\end{array}$ \\
\hline
\end{tabular}




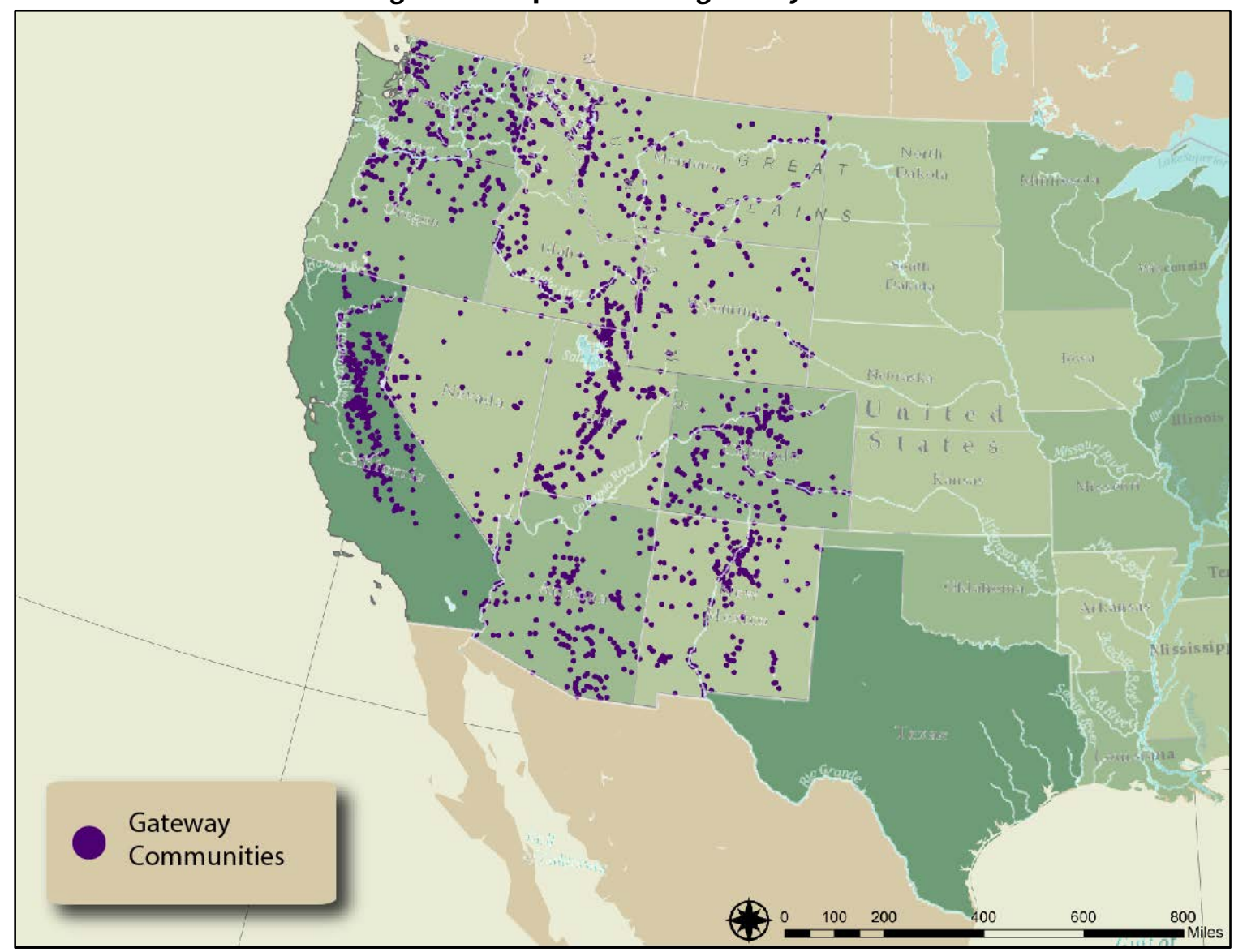

We evaluated the validity of our selection method after each sequential step. We first did this by looking for well-known GNAR communities in the sample set. Places such as Aspen, CO, Jackson, WY, Sedona, AZ, and Hood River, OR, for example, have established reputations as GNAR communities and commonly show up as case study locations in the academic literature. We also looked for lesserknown communities in regions known for their natural amenities, such as the Four Corners area. After each GNAR community attribute was operationalized and executed in ArcMap, we looked for communities dropped from the sample set due to boundary conditions. For example, setting the upper population threshold at 20,000 residents meant that South Lake Tahoe was excluded from the sample set. However, South Lake Tahoe, like the previously mentioned communities, is widely considered to be in the GNAR community typology. Similarly, we looked at communities included or excluded in the sample set based on different distance thresholds. In the course of establishing the appropriate road network distance between a GNAR community and the nearest urbanized area, we set intermediate distances that either included or excluded Sedona, AZ, whose nearest urbanized area is Flagstaff.

While this process of validating our selection criteria gives us confidence that our criteria and resultant sample population are sufficient for this preliminary study, we believe that additional quantitative and qualitative criteria could help to improve our definition of western GNAR communities. For example, we noted that Brian Head, which is a natural amenity and tourism-based 
community in southern Utah, is not included in the final set because its year-round population is less than 150 residents in the 2010 Census. However, Brian Head plays host to a large number of seasonal visitors and exhibits many of the same characteristics of the kinds of GNAR communities we are studying. We suspect there are other such anomalies that may have resulted in exclusion of certain communities that fit the GNAR community typology, and therefore believe that further exploration of the definition and criteria of a GNAR community merits further inquiry.

In order to query communities in our sample population, we needed to find contact information for public officials working within them. A team of four graduate students at the University of Utah visited the municipal websites of all communities in the sample set and, when publicly listed, recorded the email addresses and phone numbers for town/city managers, planning directors, public works directors, economic development directors, and other pertinent staff. They also recorded contact information for mayors and the chairpersons of legislative bodies. Many small and rural communities had no website and/or did not list contact information for staff. In these instances, the graduate students called the most appropriate phone number listed in conjunction with the local government entity. In some instances, a telephone call produced the staff contact information; in others, graduate students were unable to locate an individual who could represent the local government entity.

\subsection{INTERVIEWS WITH KEY INFORMANTS IN GNAR COMMUNITIES}

To begin to explore the planning and transportation-related issues in GNAR communities, we conducted in-depth interviews with a total of 33 planners, public officials, and transportation professionals in 25 intentionally selected GNAR communities. These communities were selected to represent a range of geographic locations, types of amenity/use, population sizes, and different states of tourism development. Our research team interviewed public officials representing at least one community in each of the 11 contiguous western states. Community populations ranged from 182 to 21,403 residents (2010 U.S. Census) and elevation levels from 413 feet to 8,793 feet. Average populations and elevations were 7,109 residents and 5,700 feet, respectively. Communities represented by interviewees that had tourism economies ranging from nascent to mature; some have a ski industry presence and some do not; some serve as gateways to national parks; and some serve as gateways to other types of natural amenities. We also conducted two interviews with individuals representing key regional non-profit organizations working with GNAR communities. The list of communities and organizations represented by interviewees is in Table 3.2

Table 3.2 Communities and organizations represented by interviewees

\begin{tabular}{l|l}
\hline State & Town/ Jurisdiction \\
\hline Arizona & Bisbee (1) \\
\hline California & Mammoth Lakes (1) \\
\hline & South Lake Tahoe (1) \\
\hline & Truckee (1) \\
\hline Colorado & Aspen (1) \\
\hline & Cortez (2) \\
\hline & Durango (2) \\
\hline & Ouray (1) \\
\hline & Ridgway (1) \\
\hline
\end{tabular}




\begin{tabular}{l|l}
\hline & Telluride (1) \\
\hline Idaho & Colorado Association of Ski Towns (CAST) (1) \\
\hline & Ketchum (1) \\
\hline & Sandpoint (1) \\
\hline Montana & Victor (1) \\
\hline & Big Sky (2) \\
\hline New Mexico & Whitefish (1) \\
\hline Oregon & Silver City (2) \\
\hline & Hood River (1) \\
\hline Utah & Joseph (1) \\
\hline & Klamath Falls (1) \\
\hline & Bear Lake (1) \\
\hline & Moab (2) \\
\hline Wyoming & Park City (2) \\
\hline & Springdale (1) \\
\hline & Wayne County/Torrey (1) \\
\hline & Jackson (1) \\
\hline & Valley Advocates for Responsible Development (VARD) (1) \\
\hline
\end{tabular}

We sought to generate qualitative data that would inform our understanding of the key planning and policy issues in GNAR communities. We wanted to determine primary barriers and solutions for responding to challenges and opportunities, as well as the tools, resources, and capacity building that would be most helpful to GNAR communities in their future planning and policy efforts. We also aimed to develop a better sense of how public officials describe their communities' characteristics, and how they viewed their professional roles in responding to or guiding development trends.

Interviews were semi-structured, meaning a set interview protocol was used for all interviews, but the interviewer also diverged from this protocol as needed to gather pertinent information. The interview protocol, which is included in Appendix A, asked about key transportation and planning-related challenges facing these communities, and the impacts of these issues on mobility, access to opportunity, and livability. It also asked questions about potential solutions or strategies for addressing these challenges - both those that have been attempted and those that are or could be considered - and gather lessons learned. Interviews also examine key capacity needs and constraints limiting these communities' ability to address their transportation and planning-related concerns and seek to generate insights regarding what kinds of tools, knowledge transfer, and capacity building might assist in addressing these limitations. Additionally, we used interviews to test the validity of our GNAR community selection method and to gather information on GNAR community typologies. Interview questions were designed to be intentionally open-ended, so as to not steer participant responses in any direction.

Our research team emailed interview solicitations to between one and three public officials whose email addresses were publicly available for each community. We primarily sought out mayors and council members, town managers, planning directors, and economic development directors. In many 
communities, one of the targeted public officials forwarded our request to a different individual within their organization. In some communities, we could not reach any public official willing to participate in an interview. In total, 33 individuals representing 25 GNAR communities and two regional organizations accepted our interview solicitation.

Interviews were conducted in person or over the phone and generally lasted about 60 minutes. Interviews were recorded (unless permission to record was not provided) and then transcribed into memos capturing all key ideas, representative quotes, and interviewer observation. Where permission to record was not provided, the interviewing team took careful notes and used these to develop the interview memo. In order to validate interview memos, we emailed a draft to the interviewee no more than two weeks after the date of their interview to provide an opportunity for correction or clarification. Once the public official provided changes and approval, the interview transcript was considered final.

Interview memos were coded and analyzed using Atlast.ti software. A list of codes was developed to reflect key themes (see list of codes in Appendix B); this list of codes was developed iteratively by a team of two researchers and was reviewed separately by the Principal Investigators prior to interview coding. Two researchers than used this list of codes to independently code each interview memo. They then collectively reviewed their coded memos for consistency, and any discrepancies were discussed until the two researchers reached a consensus on the final coding for each interview transcript. Interviews memos were qualitatively and quantitatively analyzed using the Atlas.ti software to identify and examine emerging themes. The key themes that emerged from interviews were used to develop our survey questionnaire, as explained below. These themes are discussed in the Results section of this report.

\subsection{ONLINE SURVEY OF WESTERN GNAR COMMUNITIES}

The results of in-depth interviews were used to develop a survey tool, which was then administered electronically to public officials in all of the identified western GNAR communities $(n=1,278)$. Based on the results of interviews, we identified the following key topics and developed related questions to collect relevant data: community demographics and dynamics; valued community characteristics; community challenges and related responses; transportation; housing; and capacity and resource needs. The questions were a combination of Likert-scale, multiple choice, and open-ended questions. The questionnaire used for the online survey is included in Appendix $C$.

Prior to administering the survey, we piloted the questionnaire with multiple academic colleagues and planning practitioners in GNAR communities to ensure clarity and relevance of questions. Once the questionnaire was finalized, we administered it using Qualtrics software. The survey was sent out via Qualtrics in June 2018, with 1,278 questionnaires distributed to the email accounts in our GNAR community database. Recipients were incentivized to take the survey by being entered into a prize drawing upon their completion of the full survey. Each week after the initial distribution, we sent reminders to those who had not completed the questionnaire within four weeks. The survey remained open until September 2018. 
Of the 1,278 initial emails sent, 22 emails were invalid and 10 duplicate emails were removed. We received completed surveys from a total of 336 respondents; three respondents did not indicate which communities they work for so those responses were removed from analysis, leaving a total of 333 respondents - a $26 \%$ response rate. A total of 263 GNAR communities were represented in this sample; while some of our respondents represented townships or small cities, others represented counties or multiple towns.

The data was exported from Qualtrics and cleaned in Microsoft Excel. All statistical analysis was performed in SPSS. We calculated descriptive statistics for every question used in the analysis. ${ }^{2}$

Since we hypothesized that the challenges that the GNAR communities are experiencing might be related to factors such as population growth, demographic changes, and changing housing stock, we sought objective measures of these variables for the communities that responded to the survey. The demographic data collected for these communities came from the U.S. Census' American Community Survey (Manson et al., 2018). The data reflects five-year estimates from the years 2010 and 2016. Data collected for both of these years was data on population, median household income (adjusted for inflation) and housing tenure. Housing tenure data showed total number of occupied housing units, number of owner-occupied housing units, and number of renter-occupied housing units. These census data were used to compare trends in our respondent communities to national trends, as discussed below in the Results section.

\subsection{OBSERVATION}

To add additional nuance and insight to our broader research, we worked with and observed ongoing planning and transportation efforts in the regions around Zion National Park and Moab, UT, and Sandpoint, ID. Prior to the project, Dr. Rumore had worked with stakeholders in the Zion National Park and Sandpoint regions for more than two years to help them collaboratively address their transportation and planning-related challenges. Ph.D. student Levine lives in and works with the region around Moab. Throughout the course of this project, we continued to work with these places and were able to observe, learned from, and ground our interview and survey findings though observation of these regions and the communities in them. Where relevant in this report, insights from our ongoing engagement and observation in these GNAR communities is used to augment interview and survey data.

\footnotetext{
${ }^{2}$ Further statistical analysis, such as to explore relationships between variables, but will be discussed in forthcoming peer-reviewed academic journal publications and not in this report.
} 


\subsection{RESULTS}

The findings from our multipronged data collection were intended to be complementary. We therefore discuss the results from these different datasets - including where they align and where they differ - in tandem below. In this report, we focus on sharing only high-level, descriptive findings so as to prevent any conflict with future peer-reviewed publications. Results from additional analysis will be presented in forthcoming journal articles.

\subsection{KEY THEMES FROM INTERVIEWS}

As noted in our Methods section, a qualitative analysis of key informant interviews was used to inform the design of our online survey questionnaire. The following key themes were prominent in the responses from interviewees:

- Demographic changes, and the importance of local natural resources and amenities in driving migration to and visitation of the community and influencing community planning and policymaking.

- Concerns about growth, especially in the lodging and tourism sectors, presenting a threat to community character, quality of life, and social capital.

- Housing-related challenges, including concerns about affordability of housing, short-term rentals, and the intersection between the two.

- Transportation-related challenges, such as traffic, congestion, transit development and operations, inadequate downtown parking, safety, mobility, funding, and maintenance.

- The interconnectedness of housing affordability and availability, transportation infrastructure, land use, and employment opportunities in a region.

- Stresses on and concerns about community infrastructure.

- Concerns among less-developed GNAR communities about becoming more like very developed GNAR communities, such as Aspen, CO, or Moab, UT.

- A variety of community and political tensions - such as between municipalities and surrounding counties, between visitors and residents, or between long-time and newer residents - and the challenges these dynamics create for planning.

- Interplay between extractive industries and the tourism economy.

- The interconnectedness of issues across regions and need for regional solutions, and resultant need for regional collaboration.

- The use of planning experiments, similar to tactical urbanism, in order to test the feasibility and effectiveness of different interventions, especially in communities with more-developed planning departments and resources.

- The desire for additional planning support in the form of tools, resources, and capacity building. Of primary interest were case studies, topical information, ordinance libraries, networking opportunities, and professional training oriented towards working in GNAR communities.

While these themes cut across interviews, it is important to note that how these themes were discussed varied by community, and often reflected the community's level of development and maturation as a tourist destination. For instance, while infrastructure was important to all communities, less-developed communities tended to report challenges related to aging infrastructure 
whereas high-growth or mature communities tended to report challenges related to undersized infrastructure. Along similar lines, the ways in which interviewees described their communities confirmed the importance and usefulness of developing a GNAR typology with several community sub-types. Interviewees used different yet related descriptors to classify their communities, such as "mountain," "resort," "rural," "destination," "lifestyle," "choice," "bedroom," "small," "isolated," and "urbanizing."

\subsection{SURVEY OVERVIEW}

To test the generalizability of interview findings and better understand planning and transportation challenges across western GNAR communities, we developed the survey to collect data on community demographics and dynamics; valued community characteristics; community challenges and related responses; transportation concerns and solutions; housing concerns and solutions; and capacity and resource needs. The questionnaire used for the survey is included in Appendix C.

As noted above, the survey was sent to a total of 1,278 email addresses. We received a total of 333 usable responses from 263 distinct GNAR communities. The respondents represented in our sample are from all over the west, including from California (20) Oregon (38), Washington (33), Nevada (2), Idaho (39), Utah (35), Arizona (29), New Mexico (14), Colorado (79), Wyoming (21), Montana (20), and Alaska (3). ${ }^{3}$ The geographic spread of communities represented in the sample is shown in Figure 4.1.

On average, communities in our survey sample grew 7.17\% from 2010-2016, experienced high rates of growth in their housing stock, and were below the U.S. 2016 median household income. Table 4.1 shows information including mean values and standard deviations in brackets about the respondents and communities they represent.

The respondents worked primarily as public works directors (32.7\%) and planners (26.6\%), and lived in the city for which they worked (72.2\%). The list of respondent positions is presented in Table 4.2.

\footnotetext{
${ }^{3}$ Alaska was not initially included in our geography of interest. However, the survey was forwarded to communities in Alaska and the research team decided the places represented from Alaska fit the typology of a western GNAR community, so these data were included in our final dataset.
} 
Figure 4.1 Map of ZIP Code respondent locations

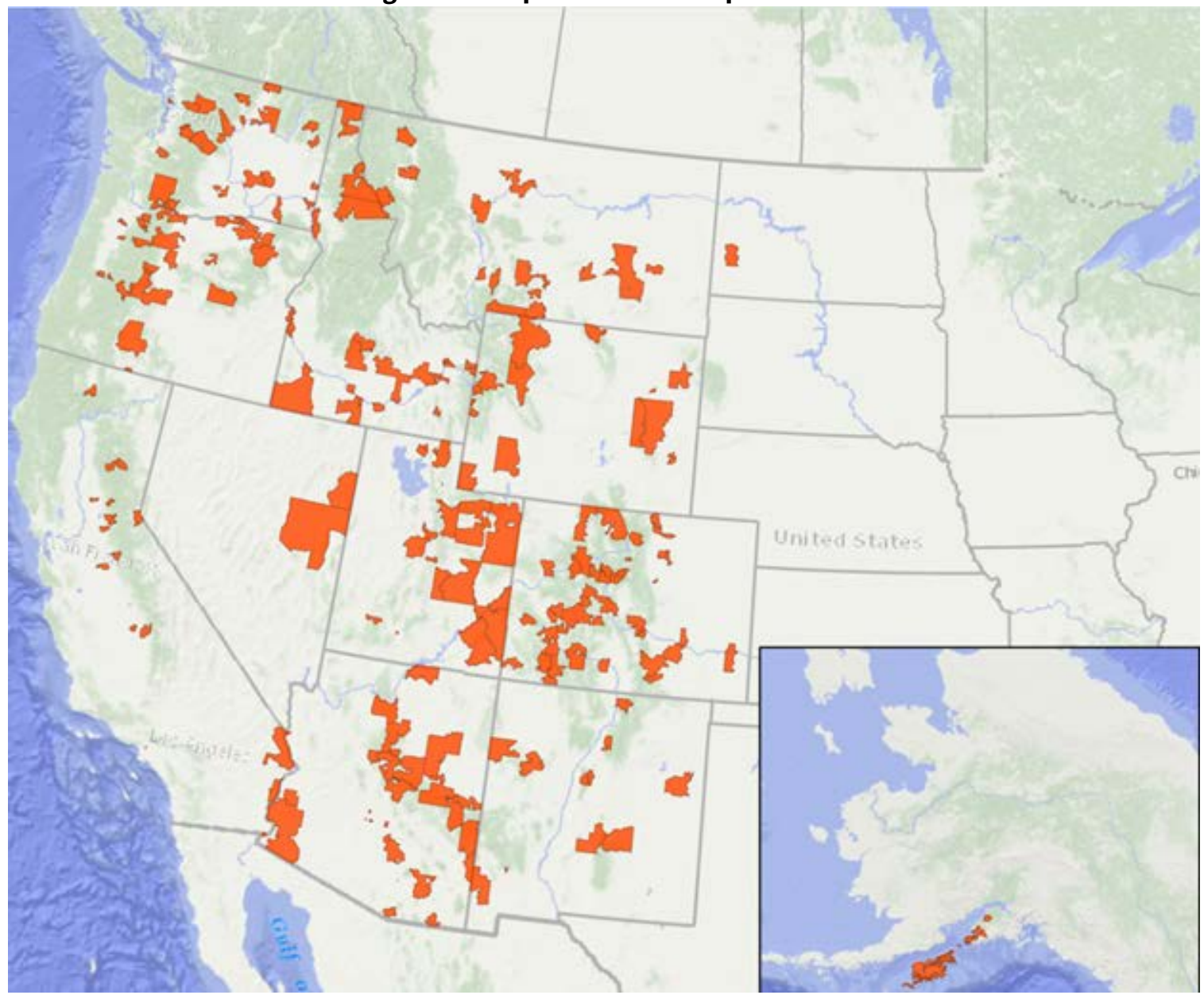

Table 4.1 Survey sample characteristics

\begin{tabular}{l|l}
\hline Number of respondents & 333 \\
\hline Number of communities & 263 \\
\hline Average median income (2016) & $\$ 49,414(\$ 16,393)$ \\
\hline Average population (2016) & $8,649(18,363)$ \\
\hline Average growth rate (2010-2016) & $7.17 \%(25.3 \%)$ \\
\hline Average growth rate of occupied housing units (2010-2016) & $32.4 \%(61.3 \%)$ \\
\hline Average growth rate of renter-occupied housing units & $65.9 \%(458.4 \%)$ \\
\hline
\end{tabular}


Table 4.2 Which of the following best describes your position with the town/city you work for?

\begin{tabular}{l|r|r}
\hline Position & Frequency & Valid Percent \\
\hline Planner & 91 & 26.6 \\
\hline Elected officials & 58 & 17 \\
\hline Private contractor & 3 & 0.9 \\
\hline Volunteer & 2 & 0.6 \\
\hline Public works director/manager & 112 & 32.7 \\
\hline Transportation planner/engineer & 69 & 20.2 \\
\hline Other & 7 & 2 \\
\hline Total & 342 & 100 \\
\hline
\end{tabular}

\subsection{KEY FINDINGS}

\subsubsection{Community Demographic Changes}

Community demographic changes surfaced as a prominent theme in our key informant interviews. Many interviewees said their communities are experiencing notable growth in population and/or increases in visitation. Many noted that a sizable portion of their population is seasonal, part-time, or second homeowners, which they noted (as further discussed below) creates economic and livability challenges.

To explore population composition and changes, the questionnaire asked a number of questions about types of residents and changes in population and visitation. Participants were asked, "What percentage of residents in your community live there year-round?" in response to which most respondents $(67.2 \%)$ reported that their communities included more than three-quarters year-round residents; $23.3 \%$ of respondents reported having half to three-quarter year-round residents; and only $9.5 \%$ of respondents reported that less than half of their populations were year-round residents (see Figure 4.2).

As indicated in Table 4.3 and Figure 4.3, when asked about the extent to which their year-round and part-time/seasonal resident population had changed in the last 10 years, the majority of respondents reported that both categories of residents had increased a little or increased substantially. Fifteen percent said the increase in year-round population had been significant, and $21.2 \%$ said the increase in part-time/seasonal population had been significant. In contrast, a total of $15 \%$ or respondents said 
their year-round population had decreased, and only a little more than $5 \%$ said their parttime/seasonal resident population had decreased.

Figure 4.2 What percentage of residents in your community live there year-round?

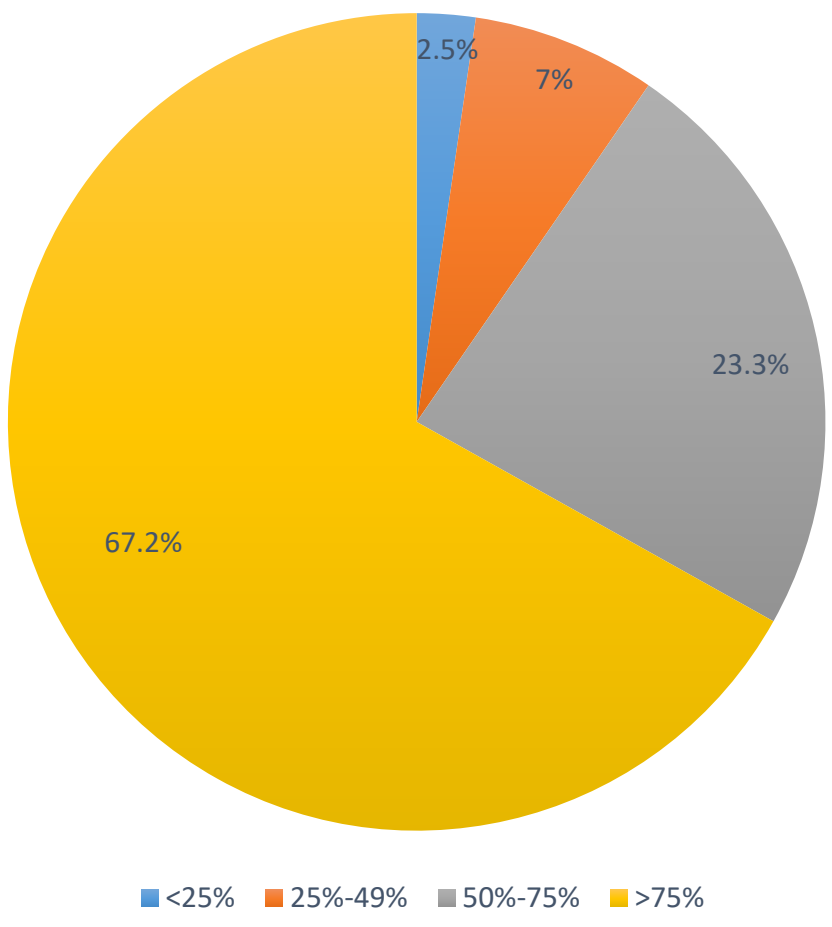

When asked whether the number of tourists visiting their community had changed over the last 10 years, $44.3 \%$ of respondents indicated their community had seen a substantial increase in visitors and another $41.9 \%$ said there had been a little increase in tourists. Only $1 \%$ indicated their community had seen any decrease in visitation.

Table 4.3 Over the last 10 years, how have the year-round residents, part-time residents, and tourists changed?

\begin{tabular}{l|c|c|c|c|c}
\hline & $\begin{array}{l}\text { Increased } \\
\text { substantially }\end{array}$ & $\begin{array}{l}\text { Increased a } \\
\text { little }\end{array}$ & $\begin{array}{l}\text { Remained the } \\
\text { same }\end{array}$ & $\begin{array}{l}\text { Decreased a } \\
\text { little }\end{array}$ & $\begin{array}{l}\text { Decreased } \\
\text { substantially }\end{array}$ \\
\hline $\begin{array}{l}\text { Year-Round } \\
\text { Residents }\end{array}$ & $15.0 \%$ & $51.8 \%$ & $18.3 \%$ & $12.0 \%$ & $3.0 \%$ \\
\hline $\begin{array}{l}\text { Part-Time } \\
\text { Residents }\end{array}$ & $21.2 \%$ & $38.5 \%$ & $34.9 \%$ & $4.7 \%$ & $0.7 \%$ \\
\hline Tourist & $44.3 \%$ & $41.9 \%$ & $12.7 \%$ & $0.7 \%$ & $0.3 \%$ \\
\hline
\end{tabular}


Figure 4.3 Over the last 10 years, how have the year-round residents, part-time residents, and tourists changed?

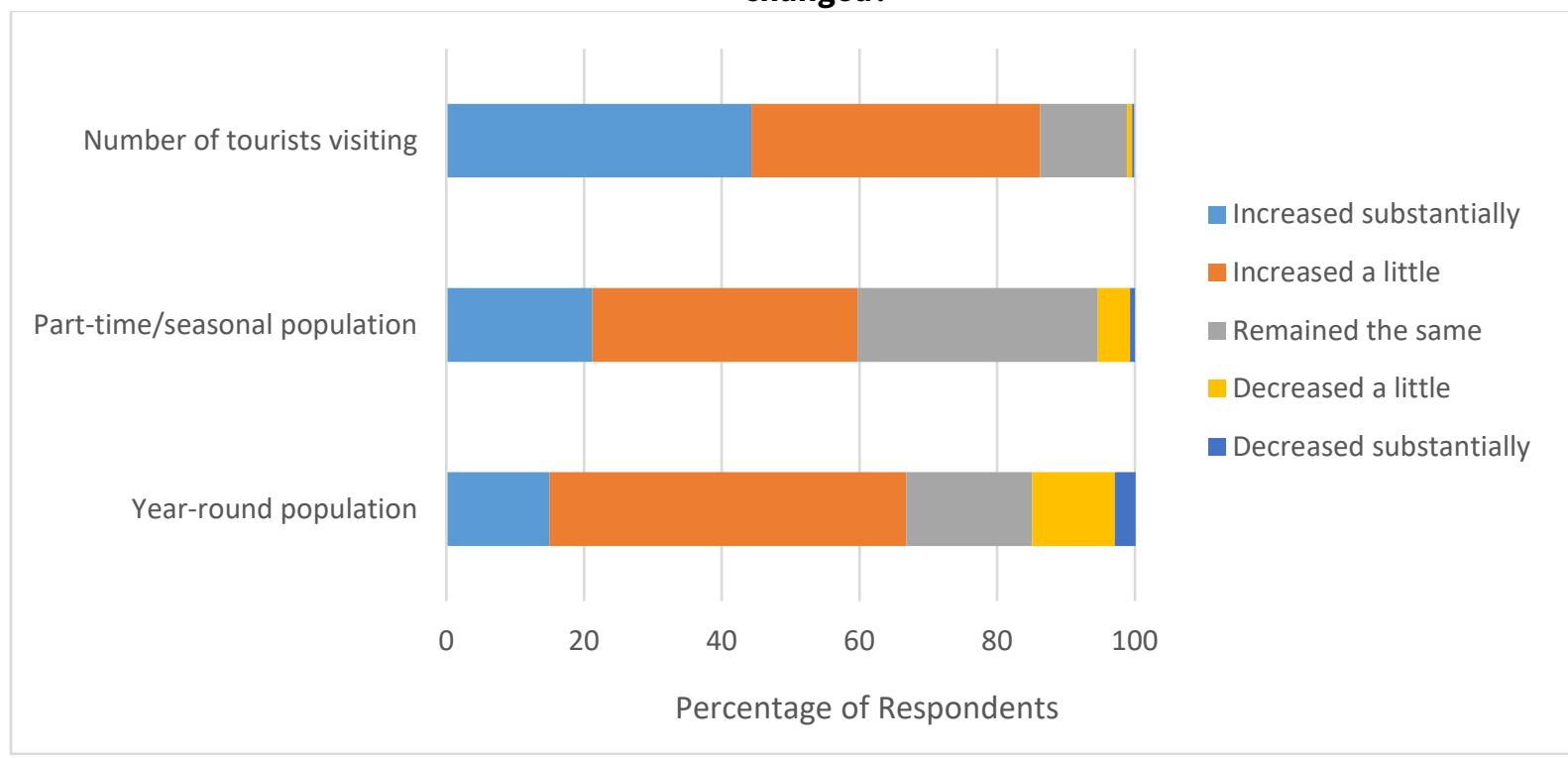

These findings from interviews and the survey align with our observation and work in GNAR communities, as well as findings from existing literature (e.g., McGranahan, 1999; McGranahan, Marcouiller, Clendenning, and Kedzior, 2002; and McGranahan, Wojan, and Lambert, 2011) and secondary data, in demonstrating that many western GNAR communities are: 1) growing, sometimes rapidly; and/or 2) experiencing significant, sometimes dramatic, increases in visitation. These results also provide useful demographic data that can be used to assess how community growth and visitation changes correlate with certain kinds of community dynamics and challenges, which we will explore in future publications.

\subsubsection{Role of Tourism in the Local Economy}

Interviewees commonly noted that their community and/or other GNAR communities have made - or are in the process of making - a transition from historical extractive-based industries (such as mining, energy extraction, grazing, or logging) to tourism and related economic activities. Interviewees also suggested this transition is often a source of tension. Both of these findings align with our observation, findings from prior studies, and our review of secondary data. To further explore the role of tourism in GNAR communities' economy, especially in relationship to natural resource industries, the survey inquired about the importance of different industries to the local economy.

In response to the question, "Which statement best describes the role of tourism in your local economy?" a majority of survey respondents said that tourism is either a vital (43.8\%) or substantial $(17.6 \%)$ part of the local economy. Only $3.3 \%$ said tourism is unimportant. 
When asked, "What role do natural resource industries like mining, forestry, and energy development play in your community's economy?" $40 \%$ said that they were a substantial or vital part of the local economy, $22 \%$ said that these industries were small but important to the local economy, and $38 \%$ of respondents said that these industries were unimportant or small and marginal in the local economy. See Table 4.4.

Table 4.4 Role of tourism and natural resource industries (like mining, forestry and energy development) in local economy

\begin{tabular}{l|c|c|c|c|c}
\hline \multicolumn{1}{c|}{ Industry } & Unimportant & $\begin{array}{c}\text { Small and } \\
\text { Marginal }\end{array}$ & $\begin{array}{c}\text { Small but } \\
\text { Important }\end{array}$ & Substantial & Vital \\
\hline Tourism & $3.3 \%$ & $12.4 \%$ & $22.9 \%$ & $17.6 \%$ & $43.8 \%$ \\
\hline $\begin{array}{l}\text { Natural resource industries } \\
\text { (mining, forestry, and energy } \\
\text { development) }\end{array}$ & $15.2 \%$ & $23.4 \%$ & $21.1 \%$ & $18.8 \%$ & $21.5 \%$ \\
\hline
\end{tabular}

These results provide evidence that tourism is a key economic driver for many western GNAR communities, which fits with the above-discussed finding that tourism is increasing in many of these places. These data also suggest that, on average, natural resource industries play a less vital role but are still important in many GNAR communities' economies. Like the community demographics data discussed above, these data can and will also be used to evaluate the extent to which certain kinds of GNAR communities, such as those with more or less reliance on tourism, are experiencing certain kinds of issues.

\subsubsection{Valued Community Characteristics}

Regardless of the population size, geographic location, dominant political affiliation, and economic prosperity of the community they represented, every single interviewee emphasized the importance of community character and sense of place to their community's identity and community members. Interviewees commonly spoke about the importance of a "small-town feel," access to high-quality natural spaces and outdoor recreation opportunities, and general livability and quality of visitor experience.

To further explore valued community characteristics, as well to gain insight into community agreement (or lack thereof) about these characteristics, we developed a list of 19 community characteristics mentioned by interviewees. We then asked survey respondents to indicate whether each of these characteristics seems to be important for the entire community, more than half of the community, less than half of the community, or not important for the community. Figure 4.4 displays the community characteristics that respondents identified as most widely valued by their communities. 
Figure 4.4 For the following community characteristics, please indicate whether they seem important for the entire community, important for more than half of the community, important for less than half the community or not important.

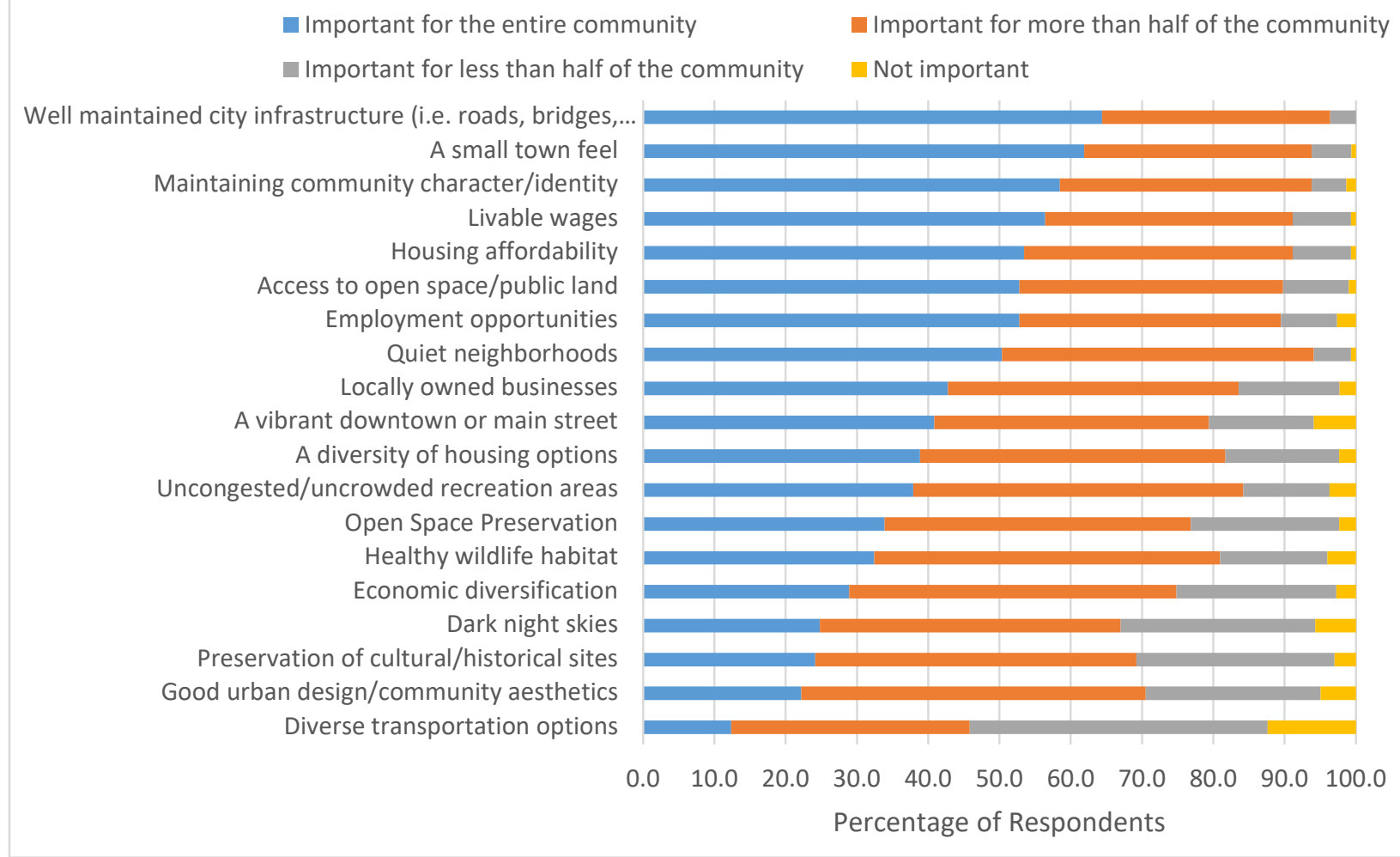

As shown in Figure 4.4, the majority of respondents identified almost all of the provided community characteristics as being important for more than half or their entire community, including: wellmaintained infrastructure, a small-town feel, maintaining community character/livability, livable wages, housing affordability, access to open space/public land, quiet neighborhoods, a vibrant downtown or main street, a diversity of housing options, open space preservation, healthy wildlife habitat, and good urban design/community aesthetics. The only characteristic provided that less than $50 \%$ of respondents identified being important for more than half of their community was "diverse transportation options." It is worth noting, however, that more than $10 \%$ of respondents identified this as being important for their entire community and about $30 \%$ said this was important for more than half of their community, and only a little more than $10 \%$ of respondents said diverse transportation options are not important for their community members.

These data suggest that, at least among GNAR communities represented in our sample, there tends to be a lot of agreement about key characteristics that community members value. Our observation and work in GNAR communities reinforces this finding that these characteristics tend to be important to community members. We also suspect that certain community characteristics, such as diverse transportation options and good urban design, become more of a concern as communities develop and experience development and transportation pressures. This merits further exploration, and will be examined in future publications. 


\subsubsection{Quality of Life and Visitor Experience}

Interviewees commonly identified livability as being a key value for their communities; however, they also commonly felt that livability in their community is at risk due to growth and increases in tourism. Summarizing what we heard from many other interviewees, one interviewee from an organization that works with multiple GNAR communities said about livability: "I think this is an area where everyone is struggling. Locals are trying to hold on to the community character that attracted them to their town. But, second homeowners move in and want to create the same type of community and environment from where they came. So there are some pressures between locals and second homeowners." Interviewees from some GNAR communities expressed similar concerns about impacts on visitor experience.

To explore these dynamics further, we asked survey respondents: "In general, do you think the quality of life for year-round residents in your community has gotten better or worse over the last 10 years?" They were asked the same question for part-time/seasonal residents, as well as a similar question for quality of visitor experience.

On average, and in contrast to perspective shared by interviewees, the majority of respondents indicated quality of life for both year-round and part-time/seasonal residents had improved (Figure 4.5). However, some respondents said quality of life had declined, raising questions about whether certain levels of growth and increases in visitation, or other factors, are associated with perceived decrease in quality of life.

Figure 4.5 To what extent do you think the quality of life for year-round residents, part-time/seasonal residents, and tourists has gotten better or worst over the last 10 years?

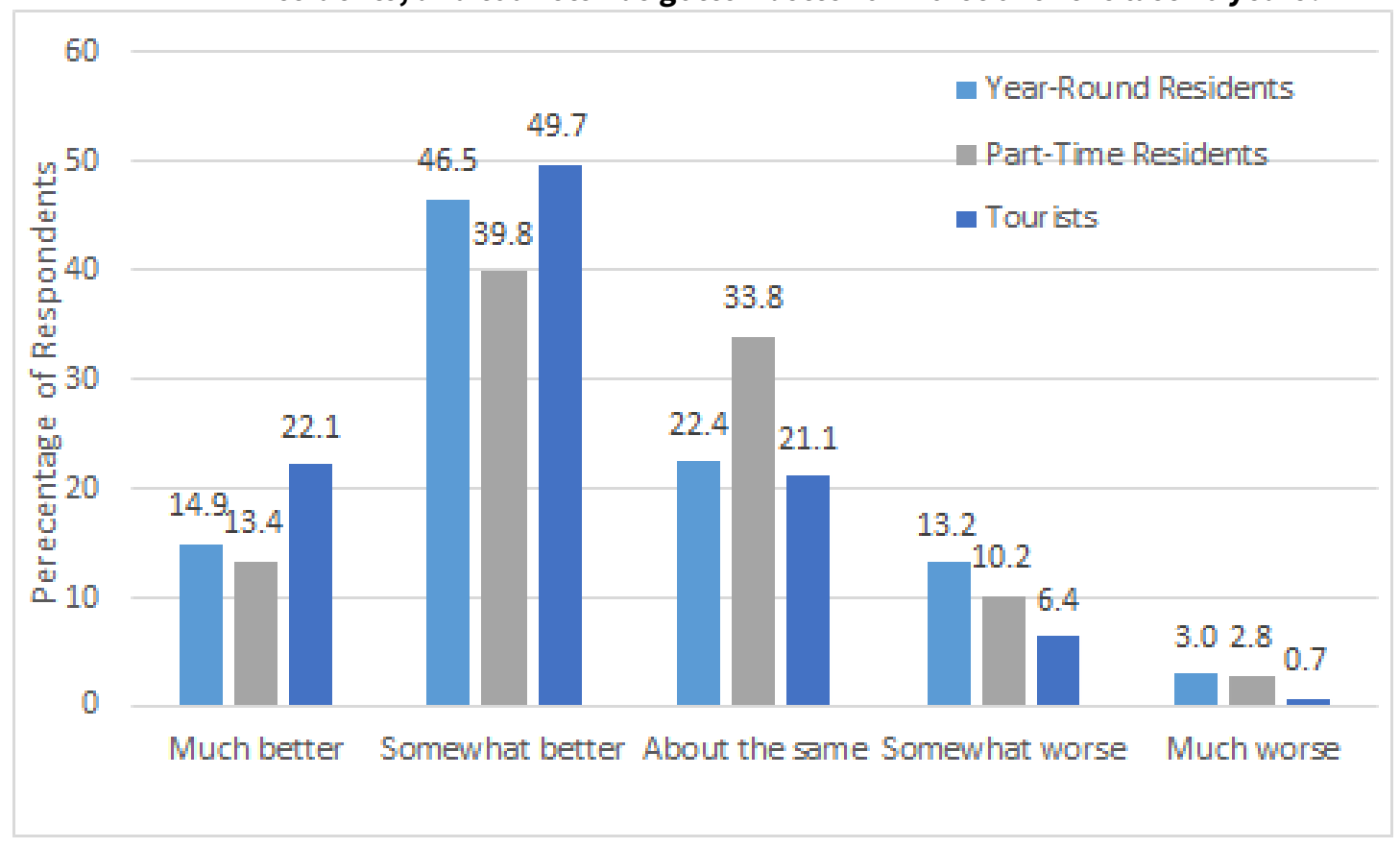

As shown in Figure 4.5, the strong majority of respondents indicated the visitor experience in their community has improved, with $22.1 \%$ saying it has gotten much better and $49.7 \%$ saying it has gotten 
somewhat better. Only $7.1 \%$ feel the tourist experience has gotten worse. As with quality of life, this raises questions about what kinds of GNAR communities are experiencing perceived decline in visitor experience.

When considered together, our survey and interview findings suggest that, as we have seen through our case studies and observation of other communities, that growth and increased visitation generally correlate with increased opportunity and are likely to increase quality of life and quality of visitor experience, at least for certain communities and certain parts of the population. However, once growth and/or visitation exceed a certain level, they may be correlated with decreased quality of life, and even with decreased quality of visitor experience. Whether this correlation bears out in our data merits further exploration, and will be analyzed in future publications.

\subsubsection{Community Tensions}

In addition to expressing general concern about the impacts of population and visitation growth on quality of life and/or visitor experience, interviewees identified a wide range of tensions associated with factions in their community and region. One commonly cited tension is that between long-time residents (sometimes referred to as "oldtimers") and recent residents (sometimes referred to as "newcomers"). This tension was sometimes seen as overlapping with, or as distinct from, a tension between "pro-growth" and "slow- or no-growth" advocates in their community. Interviewees also sometimes noted tensions between residents and tourists, and between regional jurisdictions with different political leanings (such as liberal municipalities within more conservative counties and/or states).

One interviewee characterized the oldtimer versus newcomer polarization of his community as: "There is a giant gap between the families who have traditionally lived here and the newer people who have moved here. People who have lived here a long time feel like 'if you want to move here and make it like wherever you came from, just move back there,' and the newer people see the older residents as obstructing change and growth." Public officials representing communities that were transitioning away from coal mining and other extractive industries characterized the tension as differing views about their economic future. Another said of his community: "There are two sets of visions, and I don't think they're shared. The population who have been here want new jobs to replace mining jobs and things for children to do, and the retirees want outdoor recreation and tourism."

In contrast, some interviewees said their community has not experienced an oldtimer versus newcomer dynamic, that people's perceptions of this tension are inflated, or that their community has experienced some of this tension, but it has disappeared since their community experienced its major demographic changes.

To explore the extent to which the oldtimer versus newcomer tension seems to be playing out across western GNAR communities, we asked survey respondents, "To what extent does your community have tensions between long-term residents and recent residents?" As shown in Figure 4.6, the majority of respondents indicated there is little tension (42.3\%) or none at all (17.2\%). Only $12 \%$ reported a lot or a great deal of tensions between long-term and recent residents. 
Figure 4.6 To what extent does your community have tensions between long-term residents and recent residents? To what extent does your community have tensions between residents and tourists?

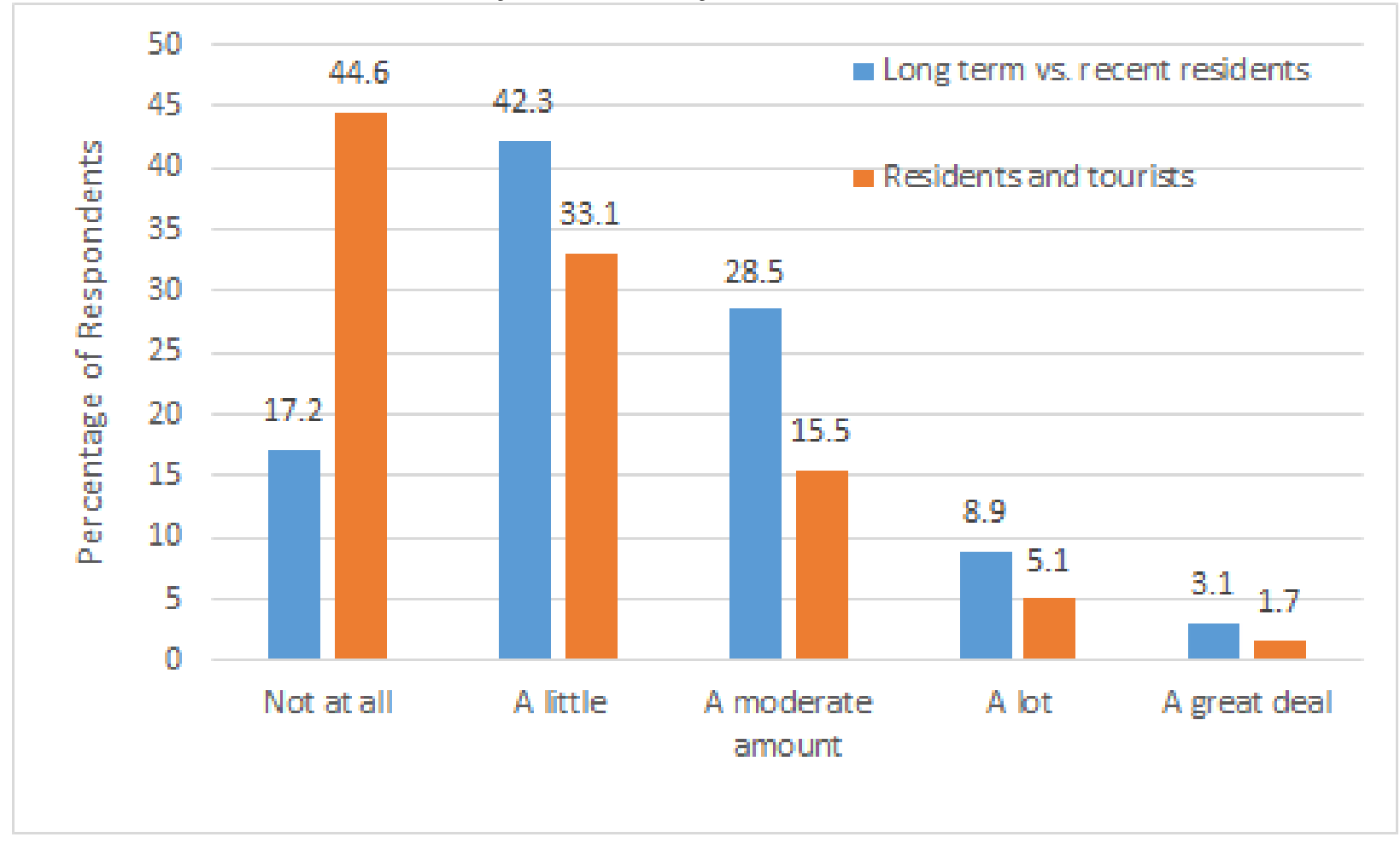

To explore the generalizability of the anecdotal reports we have heard of tension between residents and tourists, particularly in highly visited GNAR communities, such as Moab, we asked respondents "To what extent does your community have tensions between residents and tourists?" The strong majority of participants indicated that there is little $(33.1 \%)$ or no $(44.6 \%)$ tension between these two groups in their community. Less than $7 \%$ reported a lot or a great deal of tension between residents and tourists (Figure 4.6).

We suspect that demographic changes and economic growth are correlated with tensions between long-time residents and new residents, as well as tensions between residents and tourists. Our descriptive results suggest the dynamics between the population segments are complex and merit further exploration.

\subsubsection{Challenges in GNAR Communities}

A driving interest behind this research was to better document and understand the planning and development challenges facing western GNAR communities. To gather data on this, we drew upon results from interviews to generate a list of 12 commonly identified GNAR community challenges, ranging from traffic/congestion to housing affordability to changes in community character. We then asked survey respondents to indicate the extent to which each of those challenges was problematic for their communities using a Likert scale, with 1 indicating not at all problematic and 5 being 
extremely problematic. The list of challenges we provided participants and the breakdown of responses are provided in Figure 4.7. ${ }^{4}$

Figure 4.7 To what extent are the following challenges problematic in your community? [ $1=$ not at all problematic; $\mathbf{3}$ = moderately problematic; and $\mathbf{5}$ = extremely problematic $]$

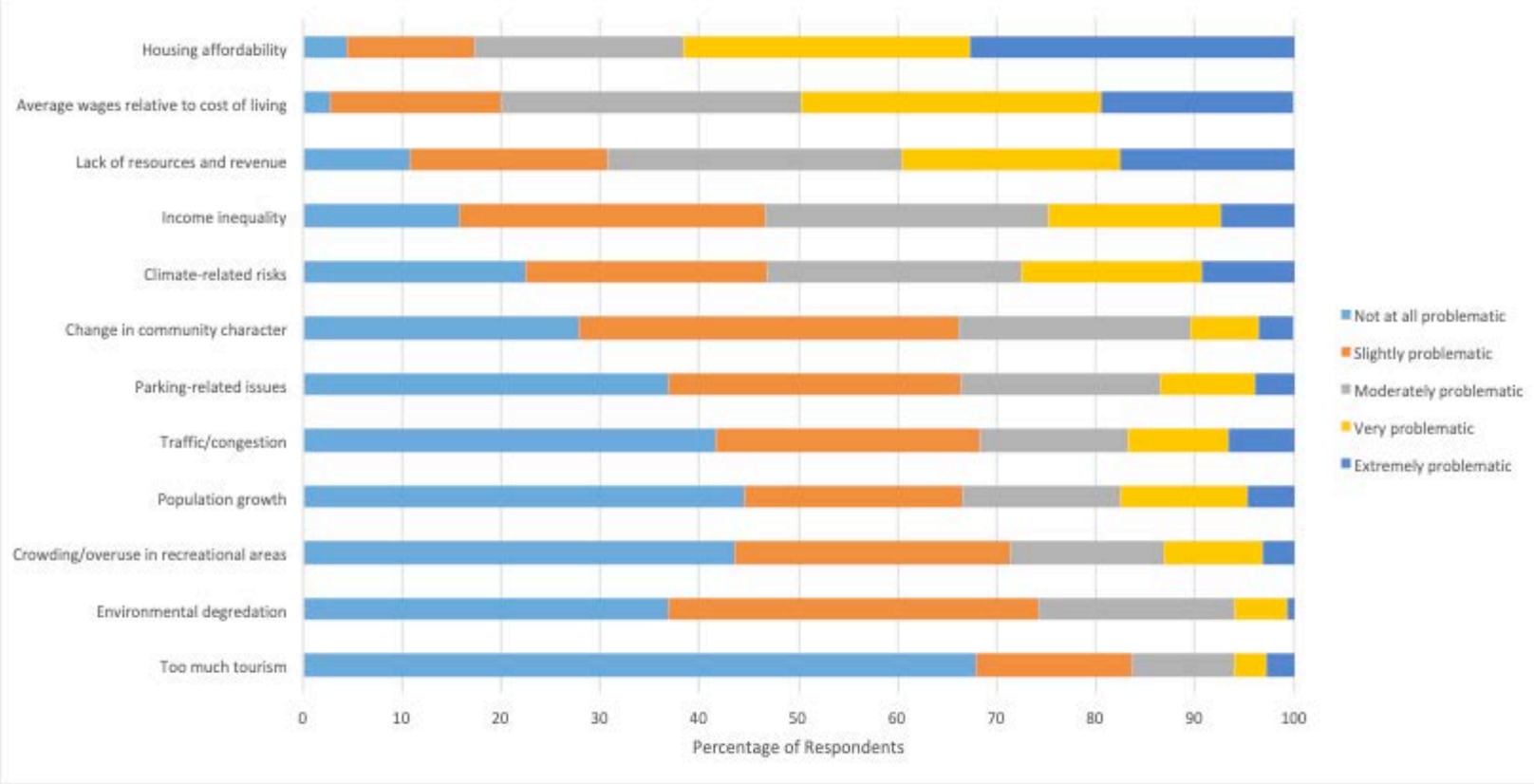

On average, respondents indicated that of the challenges provided "housing affordability" was the most problematic for their community, followed by "average wages relative to cost of living," "lack of resources and revenue," "income inequality/social inequality," and "climate-related risks." Importantly, at least some survey respondents said that all of the 12 identified challenges are extremely problematic for their communities, with only "too much tourism" and "environmental degradation" being the only two issues that less than $10 \%$ of respondents identified as being very or extremely problematic.

It is worth noting, there is some alignment and some incongruity between our interview and survey results. For instance, housing affordability and availability in GNAR communities was described as a moderate to severe challenge by all 33 of our interviewees and was also identified by the majority of survey respondents as being moderately to extremely problematic. In contrast, our interviews led us to suspect that traffic/congestion, population growth, crowding/overuse in recreation areas, and too much tourism would be identified as moderately to extremely problematic by a higher proportion of survey respondents.

These results suggest that the key issues identified by interviewees are being experienced by many GNAR communities, as we hypothesized. They also suggest that certain issues are more predominant in certain communities. Further analysis is needed to explore whether certain kinds of communities,

\footnotetext{
${ }^{4}$ The survey provided respondents an opportunity to identify "other" problems their community is facing (i.e., problems that were not included in our list of challenges). "Other" problems identified by participants are listed in Appendix D.
} 
such as those that are farther along the development trajectory or those that rely on certain kinds of tourism or development, are more prone to certain kinds of issues. This will be explored in future publications.

\subsubsection{Transportation in GNAR Communities}

Our observation of and work in GNAR communities and review of prior research and secondary data led us to hypothesize that transportation issues are an important, and sometimes acute, concern in many GNAR communities. Thus, a predominant driver of this research was an interest in better understanding the transportation-related issues in GNAR communities, their prevalence, and their connectivity to livability and mobility.

When discussing community challenges, all 33 interviewees discussed the importance of transportation infrastructure and the need for additional investments into it. However, this tended to look differently for more developed GNAR communities than it did for less-developed GNAR communities.

Interviewees from highly developed GNAR communities often cited severe and urgent challenges related to traffic, congestion, and parking. They mentioned transportation concerns associated with big events, peak visitation season, and employee commuting. Less-developed GNARs tended to talk more about the importance of or need for access to a larger transportation network.

The majority of interviewees (22 individuals representing 18 communities) described transportation planning as a regional-scale issue, noting that there is often a regional "commuter shed" around the community, that congestion and mobility issues often are regional in nature, and that addressing transportation issues typically requires regional solutions and regional planning. Additionally, many interviewees noted that the main street in their community and in many other GNAR communities is a state highway, which complicated local travel and transportation planning. As one interviewee said, "Traffic - some of that's out of our control, since many of our primary streets in town are state highways, so we're at the mercy of the state for those...A lot of that is just the state having the money to invest in that."

As discussed in the section above, the survey asked participants to share their thoughts on how problematic various concerns are for their community. The responses for transportation-related concerns are shown in Figure 4.8 below. While transportation-specific problems were not the most commonly identified key issue, a little over $30 \%$ of respondents identified parking-related issues and traffic/congestion as being moderately to extremely problematic, with more than $10 \%$ saying each of these things are very or extremely problematic. In light of the fact that these are small towns and cities in rural areas, this is an important finding.

Despite some communities experiencing transportation challenges, most respondents $(79.7 \%)$ indicated that it was extremely easy or somewhat easy to travel around their community. Additionally, when asked, "How satisfied are residents with the transportation options available in your community?" the majority of respondents (51.1\%) indicated that residents were either extremely satisfied or somewhat satisfied the transportation options available to residents. When asked, "How satisfied are tourists with the transportation options available in your community?" the majority of 
respondents said extremely or somewhat satisfied. Worth note, however, a little more than $20 \%$ of respondents said residents are somewhat to extremely dissatisfied with transportation options, and just a little less than $20 \%$ said the same was true for tourists.

Figure 4.8 In general, how easy or hard is it to travel around your community?

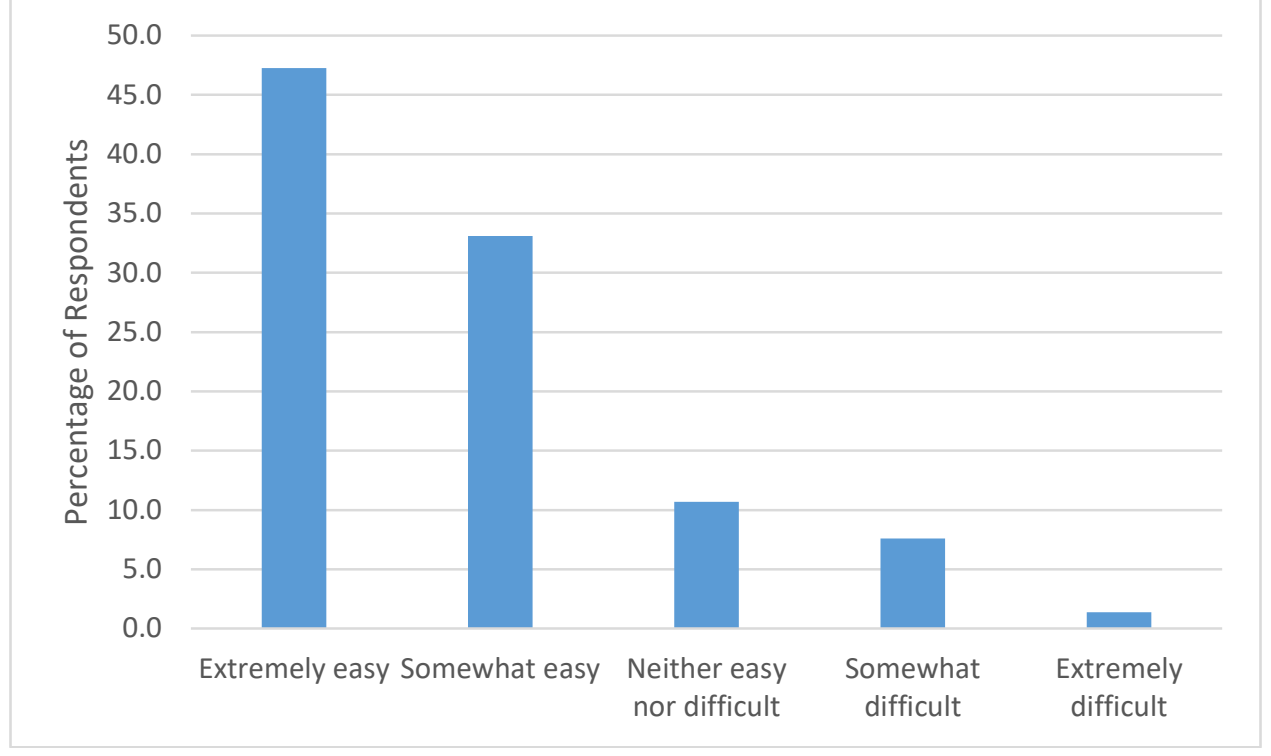

Figure 4.9 How satisfied are residents/tourists with the transportation options available in your community?

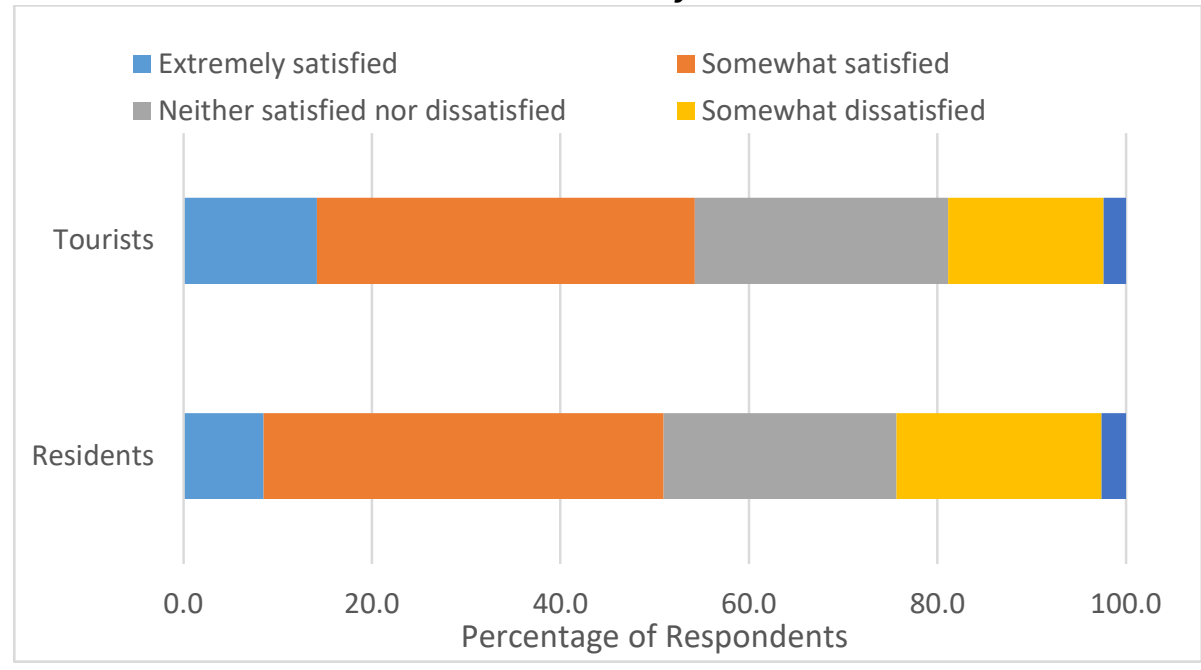

To better understand current transportation options available in GNAR communities, we asked respondents what transportation options existed in their communities. Of the options provided (this list of which was informed by interviews), sidewalks, free parking, and bike/multiuse trails were the most frequently reported transportation options (Figure 4.10). Interestingly, in light of the fact these are small rural communities, $33.3 \%$ reported having paid transit options, $22.4 \%$ reported having protected bike lanes, $18 \%$ reported having free public transit, and $6.8 \%$ reported having bike share programs. Additionally, six GNAR communities have e-bike sharing programs, and we know from our 
work in the Zion National Park region that many communities in that area are exploring the possibility of a regional e-bike share program. Figure 4.10 Transportation options in gateway communities: Which of the following transportation
options exist in your community? (select all that apply)

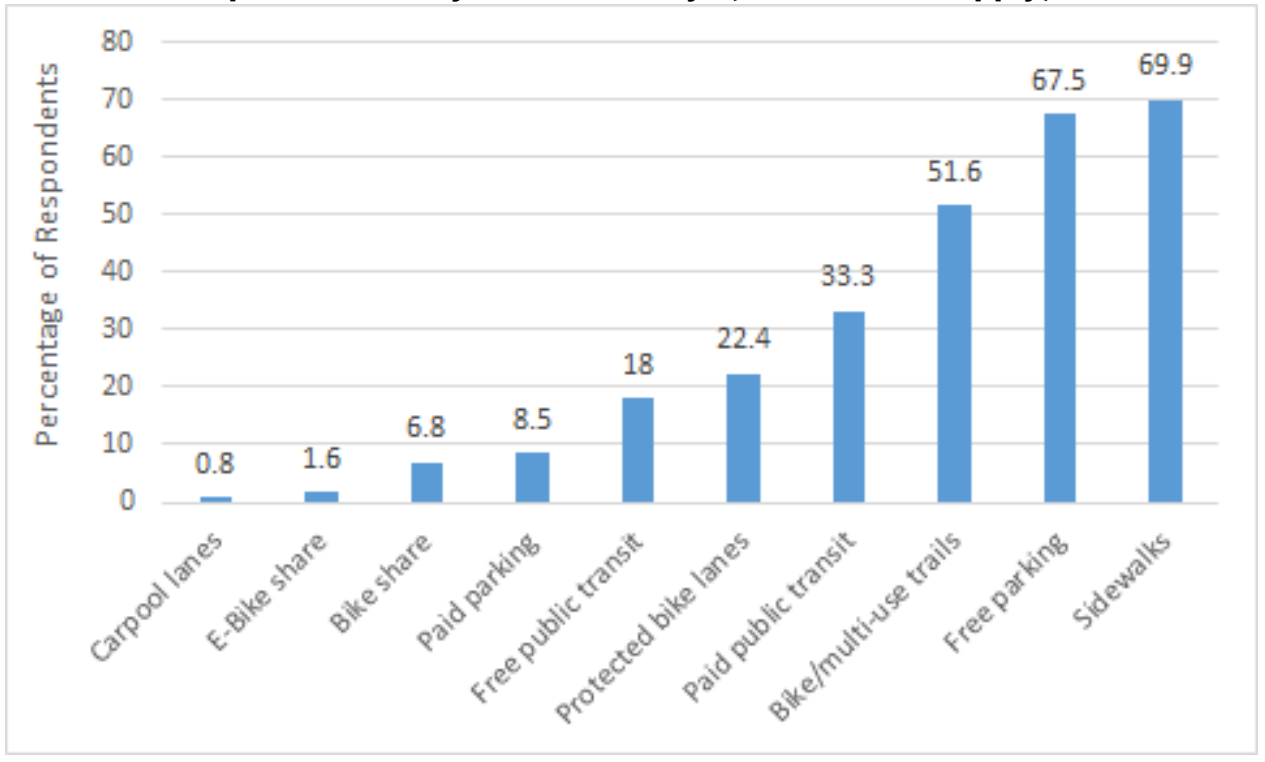

Taken together, these data reinforce our hypothesis that transportation issues are challenging in many GNAR communities, and acute in at least some. However, these data also suggest that transportation issues are not seen as a key problem in a large portion of GNAR communities, and that many of these small towns and cities are doing interesting and sometimes innovative things to address their transportation concerns. As with many of the challenges identified though this research, we suspect this may have a lot to do with where the community is at in its development trajectory, as well as perhaps other conditions of the community, such as whether the town or city has a highway as a main street and/or the level or kind of visitation the community typically experiences. These dynamics merit further exploration, and will be analyzed in future publications.

\subsubsection{Housing in GNAR Communities}

One of the most striking findings of this study is the prevalence of housing challenges in GNAR communities. Based on our work and observation of GNAR communities, we hypothesized that housing-related issues is a key challenge for highly developed and rapidly developing GNAR communities. However, the fact that all our interviewees identified housing as a key community issue and over $80 \%$ of survey respondents identified housing affordability as a moderate to extreme issue in their community is remarkable.

As with all of our findings, this result must be considered in the context of the fact these communities are small, rural towns and cities. It is therefore particularly notable that more than half of interviewees described their community's housing situation as verging on or being a crisis. As one interviewee put it, "Right now I think affordable housing is the biggest thing. Not just affordable 
housing, but actually LIVABLE affordable housing. Right now, housing is a crisis and there are a lot of people who are living in sub-standard housing because there are no other options." Another interviewee said, "Regionally, everyone's primary issue is affordable housing and local housing (both income-restricted and workforce housing)." Yet another interviewee explained, "Housing is something we've always struggled with. Although we have a great affordable housing program, there are people who want to live here who can't. As a community, we're trying to figure out what that means, and what the next phase of the housing program looks like."

Importantly, while the overwhelming majority of interviewees described their housing situation as being crises, two public officials representing low-growth GNAR communities noted that housing was not a significant challenge in their communities. As one put it, "Our city was built for about 20 thousand people, but there are only about 5 or 6 thousand now. There is a decent stock of residential housing that is vacant and becoming dilapidated."

Interviewees commonly identified interconnectedness between housing issues and other community concerns. They noted how housing demand often spills over into outlying areas in the form of "bedroom communities," which increases commuting and related impacts on transportation systems. Many also suggested that second-home development and short-term rentals are major contributors to housing market failures and their associated effects. In the words of interviewees:

"The decision not to regulate short term rentals has also removed a lot of the existing housing stock from the market."

"When homes are available, people just buy them up and turn them into AirBnbs. Now there are no places for service industry people to live and housing is getting a lot more expensive. Everyone is dealing with short-term rentals. The County and some towns are trying to regulate them to an extent. Places where rentals occur all over town really mess up towns because no one is a homeowner and there is a constant transient population"

"Short term rentals are definitely something that has impacted our housing stock, we're being proactive, we have limited areas where they're allowed, but enforcement has been challenging."

"There's a lot of demand to move here too. It's highly sought after. Second homeowners from San Francisco and Seattle are coming in with a lot more capital and so they're driving up the housing costs for everyone else in the Valley. That's why three-quarters of our housing stock is second homes."

"Housing and how to handle short-term rentals are contentious issues. [Our community] has had a history of allowing short-term rentals. It was popular even before the internet sites, but with the web this has exploded and it is taking away housing stock, particularly seasonal rentals for workers."

Along similar lines, interviewees also reported in-migration of new residents from stronger housing markets is driving up housing costs. As one interviewee put it, "If you sell a house in Los Angeles you can buy like 3 to 4 houses in [our community]." 
To explore the generalizability of these findings and better understand housing issues in western GNAR communities, we asked a number of housing-related questions in our survey. In addition to collecting data about the extent to which respondents consider housing to be an important issue in their community, we asked, "Do you believe your community is doing enough to address housing challenges?" More than twice as many respondents said they think their community is doing not enough or definitely not enough (49.2\%) to address housing challenges than said their community is definitely doing enough or almost enough (21.2\%). Worth note, most of the respondents who said their community is definitely doing enough to address housing challenges were people who had already indicated that housing is not an important problem in their community.

Table 4.6. Do you believe your community is doing enough to address housing challenges?

\begin{tabular}{l|l|l}
\hline Response & Frequency & Percent \\
\hline Definitely yes & 22 & 8.1 \\
\hline Almost enough & 36 & 13.2 \\
\hline Somewhat & 80 & 29.4 \\
\hline Not enough & 79 & 29 \\
\hline Definitely not & 55 & 20.2 \\
\hline Total & 272 & 100 \\
\hline
\end{tabular}

To get a sense of local housing markets, we asked, "What percentage of housing units in your community are occupied by year-round residents?" to which $62 \%$ of respondents said more than three-quarters, $26 \%$ said half to three-quarters , and $12 \%$ said less than half. While these self-reported measures suggest that the majority of housing in many GNAR communities is occupied year-round, it would be worthwhile to compare this to more reliable sources of data.

Table 4.7 What percentage of housing units in your community are occupied by year-round residents?

\begin{tabular}{l|c|c|c}
\hline $\begin{array}{l}\text { Proportion of housing that is occupied by } \\
\text { year round residents }\end{array}$ & Frequency & Percent & $\begin{array}{c}\text { Cumulative } \\
\text { Percent }\end{array}$ \\
\hline$<25 \%$ & 11 & $3.9 \%$ & 3.9 \\
\hline $25 \%-49 \%$ & 23 & $8.1 \%$ & 11.9 \\
\hline $50 \%-75 \%$ & 74 & $26 \%$ & 37.9 \\
\hline$>75 \%$ & 177 & $62.1 \%$ & 100 \\
\hline Total & 285 & 100 & \\
\hline
\end{tabular}

We also asked, "What is your community doing to provide affordable housing? (select all that apply)" and provided a list of 11 strategies identified through interviews. Participant responses are shown in Table 4.8.

Table 4.8 Housing strategies employed by communities, according to respondents

\begin{tabular}{l|l}
\hline Housing strategy & $\begin{array}{l}\text { Number of respondents who indicated } \\
\text { their community is using this strategy }\end{array}$ \\
\hline $\begin{array}{l}\text { Allowing or encouraging accessory } \\
\text { dwelling units }\end{array}$ & 127 \\
\hline
\end{tabular}




\begin{tabular}{l|l}
\hline $\begin{array}{l}\text { Relaxing land use/zoning } \\
\text { regulations }\end{array}$ & 86 \\
\hline $\begin{array}{l}\text { Developing publicly owned land } \\
\text { for affordable housing }\end{array}$ & 66 \\
\hline Offering density bonus incentives & 61 \\
\hline Permitting tiny homes & 61 \\
\hline $\begin{array}{l}\text { Offering impact fee or other fee } \\
\text { waiver/deferral incentives }\end{array}$ & 54 \\
\hline $\begin{array}{l}\text { Requiring and administering } \\
\text { income-based deed restrictions }\end{array}$ & 39 \\
\hline $\begin{array}{l}\text { Inclusionary zoning (aka fair-share } \\
\text { housing or community benefits } \\
\text { zones) }\end{array}$ & 35 \\
\hline $\begin{array}{l}\text { Supporting/utilizing a community } \\
\text { land trust }\end{array}$ & 20 \\
\hline $\begin{array}{l}\text { Providing rental or ownership } \\
\text { subsidies }\end{array}$ & 20 \\
\hline
\end{tabular}

These results show that GNAR communities of all shapes and sizes throughout the west are experiencing housing challenges, which are sometimes acute, and that they are trying to respond in a wide range of ways. Further analysis is needed to better understand what kinds of communities are most affected by housing concerns and why, as well as to explore the effectiveness of different strategies for making progress on housing issues.

Additionally, our interview findings suggest there is a strong nexus between housing and transportation in GNAR communities. As one interviewee said in a representative quote, "Part of the reason we have traffic issues is because people are moving farther and farther away to where they can afford to live. So, we need to continue finding ways to get people into [our city] without inundating our streets." Accordingly, many GNAR communities are trying to address these issues together, including through their land use planning. For example, one of the regional organizations we interviewed was, "Looking specifically for examples of communities tying housing and transportation together in their zoning, which might include active transportation being a part of development approvals or transit being part of a housing development." At least one community we spoke to is already doing this, stating: "We've integrated our transit/mobility plans into development approvals. So, developments need to integrate into walking/biking/bus/ shuttle systems." Inclusionary zoning is another policy GNAR communities have used to address this nexus. As one interviewee explained, "Workforce housing done right solves a lot of problems. If it's workforce housing that is infill development and accessible to transit, that addresses not just housing goals but also community character, transportation, ecosystem stewardship, social, community, and economic development goals."

All in all, this suggest that-much as in larger urban areas - there are important interconnected challenges and opportunities at the nexus of transportation and housing in GNAR communities that merit far greater study. 


\subsection{CONCLUSIONS, RECOMMENDATIONS, AND BROADER IMPACTS}

This research provides a much-needed snapshot of the status of planning and transportation challenges in western GNAR communities. To date, academic planners have largely ignored the planning context within GNAR communities. This research begins to fill this gap as well as establish the foundation for future planning and transportation research in these kinds of communities.

This study has helped establish a more rigorous definition for what a GNAR community is, which will provide a platform for future examination of these places. Building on that definition, we identified communities throughout the west that fit this typology; that database will also provide a useful platform for future research.

The data collected through this study provide evidence to support our hypotheses that:

- Many western GNAR communities are growing, sometimes rapidly, and/or experiencing significant, sometimes dramatic, increases in visitation.

- GNAR communities throughout the west are experiencing a wide range of "big-city issues" despite being small towns. Prominent among these challenges are housing affordability, average wages relative to cost of living, lack of resources and revenue, and income inequality. These challenges stand out in stark contrast to the fact these places value and identify strongly with their small-town character.

- These communities often experience unique political and cultural tensions, such as those between "newcomers" and "oldtimers" and between tourists and residents. That said, these tensions seem to be much less pervasive than we theorized.

Our findings suggest that, despite the challenges these communities face, quality of life and quality of visitor experience in many GNARs seems to have improved over the last decade. However, some respondents indicated the aspects have declined. Much the same: while most respondents indicated tensions between newcomers and oldtimers and between tourists and residents are not a major concern, some communities indicated these tensions are notable. Based on our observation and work in GNAR communities, we suspect that once GNAR communities reach a certain level of development and visitation pressure, concerns about quality of life and visitor experience, as well as tensions within the community, tend to emerge. Similarly, we hypothesize that many of these issues will become more pressing and development and/or visitation pressures will increase. Further analyses of our data will provide insight into whether this is the case, as well as generally explore what kinds of GNAR communities are experiencing certain kinds of and intensity of planning and transportation issues.

Regardless, it is clear that access to housing is a key issue across western GNAR communities. It is also evident that housing intersects in important ways with transportation and land use planning in GNAR communities, as it does in larger urban areas. We recommend that future research further explore the relationship between housing, transportation, and land use in GNAR communities, with an eye particularly on integrated strategies for improving access to housing and transportation while preserving small-town character and other qualities these communities value. Our data suggests that many GNAR communities are experimenting with innovative and promising solutions for addressing their housing concerns, and we believe much can be learned from these efforts that can assist other 
communities - whether rural or urban - in addressing their interconnected housing and transportation concerns.

This study not only provides a much-needed baseline on planning and transportation challenges in GNAR communities; it also has provided many opportunities for education and capacity building aimed at assisting western GNAR communities in tackling the issues they face. In tandem with this research, our team has facilitated collaborative planning efforts in two GNARs- one in the Sandpoint region of Idaho (the Bonner Regional Team) and one in the Zion National Park region of Utah (the Zion Regional Collaborative). These on-the-ground efforts have brought together regional stakeholders to collaboratively explore and generate solutions for their planning and transportation challenges. As a result, both regions are actively moving forward with promising collaborative efforts, such as a regional pathway and transit system in the Zion region and a multipronged regional housing strategy in the Sandpoint region. As part of this study, our team also taught a Gateway and Natural Amenity Region Planning Workshop in fall 2017 and fall 2018, which engaged eight graduate students in studying the planning challenges in GNAR communities and developing tools and resources to assist these communities. These tools are now available on our still-in-progress GNAR Community Toolkit, which is online at https://gnar.utah.edu/. Students had the opportunity to assist with and observe the Zion Regional Collaborative to gain real-world experience with GNAR community planning issues and collaborative problem solving. We also shard our findings, resources, and lessons learned at a wide range of academic and practitioner-oriented conferences and events during the grant period, including at the Stanford Bill Lane Center for the American West's "Destination: West" Conference, the Rocky Mountain Land Use Institute Conference, the American Planning Association National Planning Conference, the Mountain and Resort Town Planners Summit, and the Utah Outdoor Recreation Summit; among others. Additionally, we conducted a NITC webinar on this work.

For the last two years, we have been working on building a GNAR Initiative to provide education, research, and capacity building for gateway and natural amenity region communities throughout the west. While getting this initiative off the ground has been slower than anticipated, we now have an active website (https://gnar.utah.edu/) and numerous partners from the public and private sectors, and we are receiving requests for assistance and partnership from GNAR communities and organizations working with these towns and cities. We will continue to build this initiative and its research, education, and capacity-building endeavors as resources allow.

We are now in the process of preparing multiple articles for submission to peer-reviews publications to further explore the data collected through this study and to disseminate our research findings. We are also continuing to develop resources and tools to assist GNAR communities throughout the west. 


\subsection{REFERENCES}

Daigle, J. J., \& Zimmerman, C. A. (2004). The convergence of transportation, information technology, and visitor experience at Acadia National Park. Journal of Travel Research, 43(2), 151-160.

Daigle, J. J. (2008). Transportation research needs in national parks $囚:$ A summary and exploration of future trends. George Wright Forum, 25(1), 57-64.

Dilworth, V. A. (2003). Visitor perceptions of alternative transportation systems and intelligent transportation systems in national parks (Doctoral dissertation, Texas A\&M University).

Dunning, A. (2005). Impacts of transit in national parks and gateway communities. Transportation Research Record: Journal of the Transportation Research Board, (1931), 129-136.

Hallo, J. C., \& Manning, R. E. (2009). Transportation and recreation: A case study of visitors driving for pleasure at Acadia National Park. Journal of Transport Geography, 17(6), 491-499.

Mace, B.L., Marquit, J.D. \& Bates, S.C. (2013). Visitor assessment of the mandatory alternative transportation system at Zion National Park. Environmental Management, 52(5), 1271-1285.

Mace, B. (2014). Restoring Tranquility in Zion Canyon. Sustainable transportation in the national parks: From Acadia to Zion. Lebonon, NH: University Press of New England.

Marcouiller, D.W, Clendenning, J.G., and Kedzior, R (2002) Natural Amenity-Led Development and Rural Planning. Journal of Planning Literature, 16 (4): 515-42.

McGranahan, D. (1999) Natural Amenities Drive Rural Population Change. Agricultural Economics Reports. United States Department of Agriculture Economic Research Service, 27pp.

McGranahan, D., Wojan, T., and Lambert, D. (2010) The rural growth trifecta: outdoor amenities, creative class and entrepreneurial context. Journal of Economic Geography, 11(3): 529-557.

O’Donoghue, A. (April 15, 2016). The mighty wait at the Mighty Five (Utah's national parks). Deseret News Retrieved from http://www.deseretnews.com

Vyas, M. (2008). Gateway to Zion: Nimby and a National Park Community. In 11th National Conference on Transportation Planning for Small and Medium-Sized Communities.

Wang, Y., Veneziano, D., Russell, S., \& Al-Kaisy, A. (2016). Traffic safety along tourist routes in rural areas. Transportation Research Record: Journal of the Transportation Research Board, (2568), 55-63.

White, D. D. (2007). An interpretive study of Yosemite National Park visitors' perspectives toward alternative transportation in Yosemite Valley. Environmental Management, 39(1), 50-62. 


\section{APPENDIX A}

\section{INTERVIEW PROTOCOL}

\section{Prior to interview}

- Explain the interview process and how data will be used, etc. - Use template email

- Send the informed consent form (or bring to interview)

- Send the interview questions

\section{During the interview}

- Record the interview, if given permission

- Take detailed notes, if not

- If two people are doing the interview, have one take detailed notes during the interview, even if recording

\section{Interview Opening remarks}

- This interview is part of a research project studying planning challenges and opportunities in gateway and natural amenity communities.

- Thank you for being willing to share your thoughts on the challenges and opportunities facing your community.

- I anticipate this interview will take approximately 60 minutes.

- The information you share will be anonymized and will only be used for research purposes. Nothing you say will be attributed to you.

- Ask if it is ok to record the interview for research purposes? Recordings will only be used to help us ensure we accurately captured what you said.

- Following this interview, we will summarize your comments into an interview record. In order to validate the record, we will send it to you for review within two weeks. You will be invited to amend the record as you see fit (add, remove, or modify comments), and we ask that you complete this step within two weeks. The finalized record is what we will use for our research.

- Do you have any questions for me before we start?

\section{Interview questions}

\section{START THE RECORDER IF GIVEN PERMISSION}

1. Please state your name and title [for the recording]

2. How long have you been working/living in this area?

3. How would you say this community/region has changed in the time you've been here [or in the last 10 years, if they are new]? 
a. What is driving this change?

b. What changes do you see coming in the next $5,10,20$ years?

c. How do you and community members feel about these changes?

4. To what extent do you think people here share a vision or set of aspirations for this community?

a. How about aspirations for the broader region?

b. How so or how not? E.g., what are key areas of agreement and disagreement?

5. What do you think residents would identify as being important to quality of life in your community?

6. What role does tourism play in your community and your community's economy?

a. How do community members seem to feel about tourism?

7. What would you say are some of the key challenges your community is facing (or has faced)?

a. What, if anything, about your community "keeps you up at night"?

8. What are you doing to address the key challenges facing your community?

a. How is that working? What could be done better?

9. What are some key opportunities you think your community can capitalize on?

10. What are you doing to capitalize on these opportunities?

a. How is that working? What could be done better?

11. We've talked about [list the topic areas they have already covered]. Are there any other key challenges or opportunities your community is facing related to: [slowly go through list]
a. Planning?
b. Land use?
c. Transportation?
d. Housing?
e. Economic development?
f. Environmental things (water, natural resources, etc.)?
g. Community character and livability?
h. Tourism?
i. Politics?

12. To what extent do you think the challenges and opportunities your community is facing are unique to this place? How so or how not?

13. Are there any communities or resources you're looking to so as to help you address your challenges? Or do you know of other communities that are looking to you?

14. What tools, resources, and capacity have been particularly helpful or would be helpful for you and your community in addressing the challenges and opportunities you're dealing with? For example: 

a. Information?
b. Particular kinds of funding?
c. Planning approaches and tools?
d. Trainings?
e. Peer-to-peer learning opportunities?
f. Case studies from other places?
g. Policy changes?

15. Based on your experience, what do planners and other public officials working in communities like yours (small, rural communities outside of major natural amenities) need to know and what skills do they need to have to work effectively? For example:

a. What skills and knowledge have been particularly helpful for you?

b. What skills and knowledge do you wish you had or would like more of?

16. Is there anything else you want to share with us or anything else we should have asked about to help us understanding the planning and public policy issues in gateway and natural amenity communities?

17. Are there any other communities or individuals you suggest we look into and/or talk with?

\section{Steps for storing and processing interview data}

\section{Within two weeks of an interview}

- Save the audio file of the interview in the "Recordings" Folder in Box.

o Create a subfolder with the name of the interviewee's city.

o Use the filename structure: [IntervieweeName]_[IntervieweeTitle]

- Use the Interview Record Template.

- Using paraphrasing, write the draft record as you are listening to the audio file.

- Refer to any notes you took during the interview for additional context or insights.

- Fill in the Synthesis, Comments, Questions, and Hypotheses Table.

- Provide the Draft Interview Record to your second interviewer. If you conducted the interview yourself, provide the audio file and draft record to another member of the research team.

- The second interviewer/researcher listens to the audio file and checks for omissions or questionable paraphrasing in the draft record, making notes in Tracked Changes as necessary.

- The second reviewer/researcher adds to the SCQH Table as needed.

- You and the second reviewer/researcher agree on the draft record to be shared with the interviewee.

- Save the draft record in the "DRAFT Write-ups" Folder in Box.

- Copy and paste the draft interview record into a new document, ensure all tracked changes and comments are removed, and send the record to the interviewee. Request amendments to the draft record or confirmation of its accuracy be returned via e-mail within two weeks.

Ten days after sending the draft interview record 
- If you have not received confirmation/approval of the draft record or suggested amendments, send a friendly reminder to the interviewee.

Two weeks after sending the draft interview record (or as soon as possible)

- Review requested amendments to the draft record. Make changes to the draft record. Copy and paste the SCQH Table from the draft record into the Final Interview Record.

- Save the final, approved record in the "Approved and Validated Write-ups" Folder in Box. 


\section{APPENDIX B}

\section{INTERVIEW CODING KEY}

\begin{tabular}{|c|c|c|}
\hline Code Group & Code & Code Description \\
\hline \multirow[t]{2}{*}{$\begin{array}{l}\text { GNAR Initiative and } \\
\text { Future Research }\end{array}$} & $\begin{array}{l}\text { Case Study } \\
\text { Opportunity }\end{array}$ & $\begin{array}{l}\text { Use this code to identify any areas of possible further } \\
\text { research or a case study. This will include any and all } \\
\text { suggestions made by interviewees regarding who else } \\
\text { we should talk to, examples of successes and failures, } \\
\text { and anything that could help inform the toolkit }\end{array}$ \\
\hline & GNAR Assistance & $\begin{array}{l}\text { Includes any reference to the need for more support, } \\
\text { assistance, guidance, tools, resources, etc., which } \\
\text { verifies the need for our "GNAR Initiative" }\end{array}$ \\
\hline \multirow[b]{2}{*}{ GNAR Public Officials } & $\begin{array}{l}\text { Community } \\
\text { Familiarity }\end{array}$ & $\begin{array}{l}\text { Includes any reference to a GNAR official's level of } \\
\text { familiarity with a community, which is likely based on } \\
\text { their tenure in office }\end{array}$ \\
\hline & KSAE & $\begin{array}{l}\text { Includes any reference to knowledge, skills, abilities, } \\
\text { and education that have contributed to a public } \\
\text { official's professional capacity, or KSAEs that would } \\
\text { be helpful/necessary to a public official working in a } \\
\text { GNAR }\end{array}$ \\
\hline \multirow{3}{*}{ GNAR Public Officials } & $\begin{array}{l}\text { Planner as } \\
\text { Bricoleur }\end{array}$ & $\begin{array}{l}\text { Includes any reference to "multiple hat wearing," } \\
\text { interdisciplinary/transdisciplinary thinking, or other } \\
\text { "bricolage" related topics }\end{array}$ \\
\hline & Public Services & $\begin{array}{l}\text { Use this code for references to other public services, } \\
\text { such as fire, police, ambulance, search and rescue, } \\
\text { etc. } \\
\text { This can also be used to refer to government services } \\
\text { (such as local administration, mayor, councils, etc) }\end{array}$ \\
\hline & Staff Capacity & $\begin{array}{l}\text { Includes references to quality (+/-) or capacity (+/-) of } \\
\text { staff or staff resources }\end{array}$ \\
\hline \multirow{6}{*}{$\begin{array}{l}\text { GNARlyness } \\
\text { (economy) }\end{array}$} & $\begin{array}{l}\text { Agriculture and } \\
\text { Ranching }\end{array}$ & $\begin{array}{l}\text { Includes any reference to agriculture and ranching as } \\
\text { an economic activity }\end{array}$ \\
\hline & Economy & $\begin{array}{l}\text { Includes any reference to economic structure, } \\
\text { economic development, diversification, regional or } \\
\text { global economic drivers, or recession impacts }\end{array}$ \\
\hline & Employment & $\begin{array}{l}\text { Includes any mention of the terms 'workers' or } \\
\text { 'employees' }\end{array}$ \\
\hline & Events & $\begin{array}{l}\text { Includes any reference to events, event impacts, event } \\
\text { fatigue, etc. }\end{array}$ \\
\hline & Main Street & $\begin{array}{l}\text { Includes any reference to Main St., downtown } \\
\text { business, commercial business district, etc. }\end{array}$ \\
\hline & $\begin{array}{l}\text { Natural resource } \\
\text { development }\end{array}$ & $\begin{array}{l}\text { Includes any reference to mining, logging, oil, gas, } \\
\text { minerals, or energy development (renewable or non- }\end{array}$ \\
\hline
\end{tabular}




\begin{tabular}{|c|c|c|}
\hline & & $\begin{array}{l}\text { renewable). This code includes broad references to } \\
\text { 'development.' }\end{array}$ \\
\hline & Recreation & $\begin{array}{l}\text { This code for recreation is reserved for explicit } \\
\text { references to recreation as it related to tourism and } \\
\text { visitors and is an economic factor. Other references } \\
\text { to 'recreation' in relation to residents, quality of life, } \\
\text { or desirability, should be tagged as the "Quality of } \\
\text { Life' code. }\end{array}$ \\
\hline & Seasonality & $\begin{array}{l}\text { Includes any reference to seasonality within economy, } \\
\text { impacts of seasonality, or trends related to } \\
\text { overcoming or working with seasonality }\end{array}$ \\
\hline & Tourism & \\
\hline & $\begin{array}{l}\text { Tourism } \\
\text { Promotion }\end{array}$ & $\begin{array}{l}\text { Includes any reference to tourism or destination } \\
\text { marketing/advertising, the impacts of tourism } \\
\text { promotion on other issues, or social media as it is } \\
\text { connected to tourism growth }\end{array}$ \\
\hline \multirow[b]{2}{*}{$\begin{array}{l}\text { GNARlyness (in } \\
\text { general) }\end{array}$} & Challenge & $\begin{array}{l}\text { Includes interviewee references to planning or } \\
\text { development related challenges. }\end{array}$ \\
\hline & $\begin{array}{l}\text { Community } \\
\text { Character }\end{array}$ & $\begin{array}{l}\text { Community character is different than community } \\
\text { identity; Community character may refer to the image } \\
\text { of a GNAR that is easily seen by 'outsiders.' } \\
\text { Community Character may sometimes refer to } \\
\text { physical design elements, such as public spaces or } \\
\text { architectural forms/aesthetics }\end{array}$ \\
\hline \multirow{4}{*}{$\begin{array}{l}\text { GNARlyness (in } \\
\text { general) }\end{array}$} & $\begin{array}{l}\text { Community } \\
\text { Identity }\end{array}$ & $\begin{array}{l}\text { Includes any reference to residents' perceptions of } \\
\text { their own community. }\end{array}$ \\
\hline & GNAR Typology & $\begin{array}{l}\text { Includes any reference to characteristics that help to } \\
\text { define the GNAR typology or GNAR development } \\
\text { trajectory; Differences and similarities (real or } \\
\text { perceived) between different GNARs; Comparisons of } \\
\text { one GNAR community to another; Importance of } \\
\text { location and/or landscape feature and/or tourist } \\
\text { attraction/destination (e.g. NP); Quality of life } \\
\text { components; Destination reputation and desirability }\end{array}$ \\
\hline & Opportunity & \\
\hline & Quality of Life & $\begin{array}{l}\text { Includes any reference to quality of life in general or } \\
\text { something specific that affects overall quality of life, } \\
\text { including outdoor recreation; cost of living, noise, } \\
\text { traffic, crime, education, etc. }\end{array}$ \\
\hline \multirow{4}{*}{$\begin{array}{l}\text { GNARlyness } \\
\text { (environment) }\end{array}$} & Climate Change & $\begin{array}{l}\text { Includes any reference to climate change, adaptation, } \\
\text { or resilience }\end{array}$ \\
\hline & Dark Skies & Includes any reference to dark skies \\
\hline & $\begin{array}{l}\text { Environmental } \\
\text { Quality Indicators }\end{array}$ & $\begin{array}{l}\text { Includes any reference to environmental quality, } \\
\text { change in quality, pollution, degradation, } \\
\text { improvement, etc. }\end{array}$ \\
\hline & Federal Lands & Includes any reference to federal lands not specifically \\
\hline
\end{tabular}




\begin{tabular}{|c|c|c|}
\hline & (general) & addressed by a different code in this code group \\
\hline & Infrastructure & $\begin{array}{l}\text { Includes any reference to infrastructure not already } \\
\text { captured elsewhere. }\end{array}$ \\
\hline & Natural disasters & $\begin{array}{l}\text { Includes any reference to naturally occurring events } \\
\text { such as earthquakes, landslides, floods, avalanches, } \\
\text { etc. }\end{array}$ \\
\hline & NPS/USFS & $\begin{array}{l}\text { Includes any reference to a national park or national } \\
\text { forest. }\end{array}$ \\
\hline & $\begin{array}{l}\text { State and Local } \\
\text { Parks }\end{array}$ & Includes any reference to a state or local park \\
\hline & Sustainability & $\begin{array}{l}\text { Includes any reference to climate change mitigation, } \\
\text { adaptation, carbon neutrality, energy efficiency, } \\
\text { environmental goals, etc. }\end{array}$ \\
\hline & Water and Sewer & Includes any reference water and sewer issues \\
\hline \multirow[t]{2}{*}{$\begin{array}{l}\text { GNARlyness (land } \\
\text { use) }\end{array}$} & Accommodations & $\begin{array}{l}\text { Includes any reference to hotels, motels, short-term } \\
\text { rentals, campgrounds, or other accommodation- } \\
\text { related issues, including the impacts of STRs on } \\
\text { housing supply, demand, and pricing. This code also } \\
\text { includes mentions of ADU. Note to Researcher: Use } \\
\text { the text search function to find all specific mentions of } \\
\text { ADUs }\end{array}$ \\
\hline & Housing & $\begin{array}{l}\text { Includes any reference to market rate, below-market- } \\
\text { rate, affordable, unaffordable, or workforce housing; } \\
\text { Includes references to construction trends, costs, etc. }\end{array}$ \\
\hline \multirow{2}{*}{$\begin{array}{l}\text { GNARlyness (land } \\
\text { use) }\end{array}$} & $\begin{array}{l}\text { Land Use and } \\
\text { Development } \\
\text { Regulations }\end{array}$ & $\begin{array}{l}\text { Includes any reference to zoning, development } \\
\text { regulations, etc. }\end{array}$ \\
\hline & Real estate & $\begin{array}{l}\text { Includes any reference to the real estate industry or } \\
\text { real estate professionals, property values, or changes } \\
\text { in real estate practices }\end{array}$ \\
\hline \multirow{2}{*}{$\begin{array}{l}\text { GNARlyness (socio- } \\
\text { cultural) }\end{array}$} & GNAR Relations & $\begin{array}{l}\text { Includes any reference to the relationship between } \\
\text { the gateway community and the amenity; more } \\
\text { specifically, this will likely be the agency or } \\
\text { corporation that operates in the natural amenity. Ex: } \\
\text { Town of Springdale and NPS; Park City and Vail/Deer } \\
\text { Valley }\end{array}$ \\
\hline & $\begin{array}{l}\text { Socio-cultural (\& } \\
\text { socioeconomic) } \\
\text { Dynamics }\end{array}$ & $\begin{array}{l}\text { Includes any reference to old-timer/new-comer } \\
\text { dynamic, generational dynamics, and cultural } \\
\text { differences between neighborhoods or between } \\
\text { different towns in a region; This may also refer to } \\
\text { resident vs. visitor dynamics, and economic } \\
\text { differences, for example the haves and have-nots }\end{array}$ \\
\hline \multirow{2}{*}{$\begin{array}{l}\text { GNARlyness } \\
\text { (transportation) }\end{array}$} & Parking & $\begin{array}{l}\text { Everything coded as parking should also be coded as } \\
\text { Transportation }\end{array}$ \\
\hline & Transportation & $\begin{array}{l}\text { Includes any reference to public transit, active and } \\
\text { alternative transportation, biking, traffic, congestion, }\end{array}$ \\
\hline
\end{tabular}




\begin{tabular}{|c|c|c|}
\hline & & mobility, and airports \\
\hline \multirow{6}{*}{$\begin{array}{l}\text { Nature of Community } \\
\text { Change }\end{array}$} & Change & $\begin{array}{l}\text { Includes any reference to change: positive or } \\
\text { negative; intentional or unintentional; social, } \\
\text { economic, or environmental change; drivers of } \\
\text { change; impacts of change; etc. (If subcategories are } \\
\text { needed, they can be added later) }\end{array}$ \\
\hline & Demographics & $\begin{array}{l}\text { Includes any reference to population characteristics, } \\
\text { change in demographics, in-migration, out-migration, } \\
\text { age structure, etc. }\end{array}$ \\
\hline & Growth/Decline & $\begin{array}{l}\text { Includes any reference to growth or decline, especially } \\
\text { population or economic }\end{array}$ \\
\hline & History & $\begin{array}{l}\text { Includes references to history of community or region, } \\
\text { or historical changes/trends/dynamics }\end{array}$ \\
\hline & HTE Nexus & $\begin{array}{l}\text { Code any time there is an indication that housing, } \\
\text { transportation, and economy are interconnected } \\
\text { issues. }\end{array}$ \\
\hline & Prediction & $\begin{array}{l}\text { Includes any mention of predictions that interviewees } \\
\text { are making about the future. }\end{array}$ \\
\hline \multirow{4}{*}{$\begin{array}{l}\text { Process of } \\
\text { Community Change }\end{array}$} & Collaboration & $\begin{array}{l}\text { Includes any references to intergovernmental } \\
\text { collaboration, public-private partnerships, etc. }\end{array}$ \\
\hline & $\begin{array}{l}\text { Community } \\
\text { Engagement }\end{array}$ & \\
\hline & Design & $\begin{array}{l}\text { Includes any reference to commonly accepted notions } \\
\text { of "urban design" activities and practices }\end{array}$ \\
\hline & $\begin{array}{l}\text { Government } \\
\text { Revenue }\end{array}$ & $\begin{array}{l}\text { Includes any reference to taxes (property, sales, } \\
\text { lodging, income, etc.), grants, etc. }\end{array}$ \\
\hline \multirow{5}{*}{$\begin{array}{l}\text { Process of } \\
\text { Community Change }\end{array}$} & $\begin{array}{l}\text { Intergovernmental } \\
\text { Relations }\end{array}$ & $\begin{array}{l}\text { Includes any reference to interactions between } \\
\text { government agencies at all levels, including local, } \\
\text { state, federal or local to local }\end{array}$ \\
\hline & Planning & $\begin{array}{l}\text { Includes any reference to planning activities, } \\
\text { including visioning, master plans, economy planning, } \\
\text { zoning, etc. }\end{array}$ \\
\hline & $\begin{array}{l}\text { Planning } \\
\text { Experiments }\end{array}$ & $\begin{array}{l}\text { Includes any reference to a temporary planning } \\
\text { process or implementation tool }\end{array}$ \\
\hline & Regional & $\begin{array}{l}\text { Includes any reference to regional drivers or effects of } \\
\text { GNAR development, regional worldviews, regional } \\
\text { cooperation or noncooperation, etc. }\end{array}$ \\
\hline & Technology & $\begin{array}{l}\text { Includes any reference to change being driven by } \\
\text { technology, or planning being forced to catch up with } \\
\text { technology }\end{array}$ \\
\hline
\end{tabular}




\section{APPENDIX C}

\section{QUESTIONNAIRE USED FOR ONLINE SURVEY}

Q1 What town/city do you work for? (The rest of the questions in this survey will be about this town/city)

Q2 In which state is the town/city located?

Alabama ... I do not reside in the United States

Q3 What is the zip code for the office where you work?

Q4 How long have you worked for that town/city? (approximate number of years)

Q5 Do you live in the town/city you work for?

Yes

No 
Q6 Which of the following best describes your position with the town/city you work for?

\section{Planner}

Elected official

Private contractor

Volunteer

City manager

Public Works director/manager

Transportation planner/engineer

Other

Q7 For the following community characteristics, please indicate whether they seem to be important for the entire community, more than half of the community, less than half of the community, or not important.

Importance in the community

$\begin{array}{ccccc}\text { Important for the } & \begin{array}{c}\text { Important for } \\ \text { entire community } \\ \text { the community }\end{array} & \begin{array}{c}\text { Important for } \\ \text { less than half } \\ \text { of the } \\ \text { community }\end{array} & \begin{array}{c}\text { Not } \\ \text { important }\end{array} & \begin{array}{c}\text { Idon't } \\ \text { know }\end{array}\end{array}$




Open space
preservation
Access to open
space/public land
A small town feel
A vibrant downtown
or main street
Housing affordability
Employment
opportunities
Livable wages
areas
infrastructure (i.e.
roads, bridges, and
utilities)
Maintaining
community
character/identity
Locally owned
businesses
housing options
Healthy wildlife
habitat
options
Preservation of
cultural/historical
sites




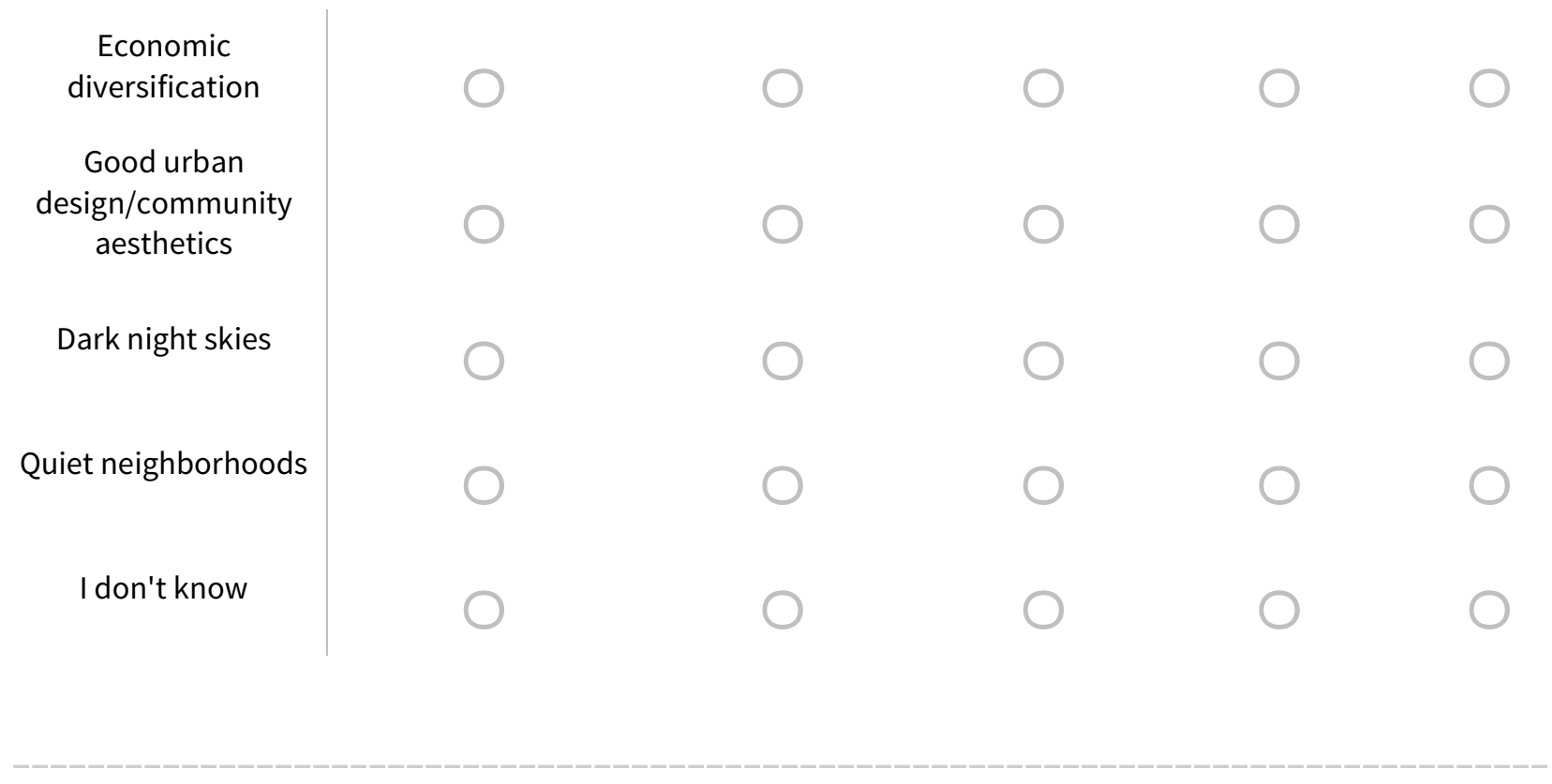

Q8 What percentage of residents in your community live there year-round?

$>75 \%$

$50 \%-75 \%$

$25 \%-49 \%$

I don't know 
Q9 Over the last ten years, the year-round population of your community

Increased substantially

Increased a little

Remained the same

Decreased a little

Decreased substantially

I don't know

Q10 Over the last ten years, the part-time/seasonal population of your community

Increased substantially

Increased a little

Remained the same

Decreased a little

Decreased substantially

I don't know 
Q11 Over the last ten years, the number of tourists visiting your community

Increased substantially

Increased a little

Remained the same

Decreased a little

Decreased substantially

I don't know

Q12 Which statement best describes the role that tourism plays in your community's economy?

Tourism is vital to our local economy

Tourism is a substantial part of our local economy

Tourism is a small but important part of our local economy

Tourism is a small and marginal part of our local economy

Tourism is unimportant to our local economy

I don't know 
Q13 What role do natural resource industries like mining, forestry, and energy development play in your community's economy?

These industries are vital to our local economy

These industries are a substantial part of our local economy

These industries are a small but important part of our local economy

These industries are a small and marginal part of our local economy

These industries are unimportant to our local economy

I don't know

Q14 In general, do you think the quality of life for year-round residents in your community has gotten better or worse over the last ten years?

Much better

Somewhat better

About the same

Somewhat worse

Much worse

I don't know 
Q15 In general, do you think the quality of life for part-time/seasonal residents in your community has gotten better or worse over the last ten years?

Much better

Somewhat better

About the same

Somewhat worse

Much worse

I don't know

Q16 In general, do you think the visitor experience for tourists in your community has gotten better or worse over the last ten years?

Much better

Somewhat better

About the same

Somewhat worse

Much worse

I don't know 
Q17 To what extent are the following challenges problematic for your community? (slide the bar to indicate your response)

I don't Not at all Slightly Moderately Very Extremely know problematicproblematicproblematicproblematicproblematic

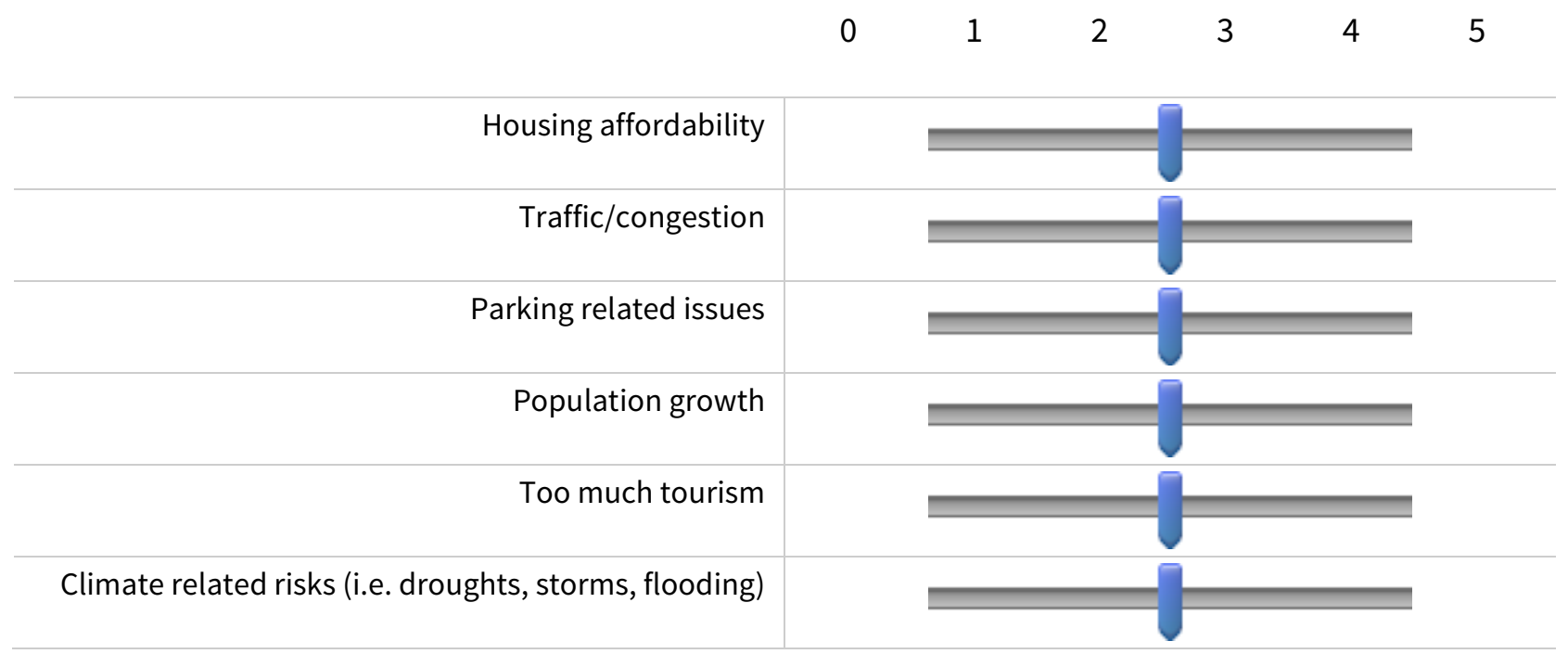

Q18 To what extent are the following challenges problematic for your community? (slide the bar to indicate your response)

I don't Not at all Slightly Moderately Very Extremely know problematicproblematicproblematicproblematicproblematic

$\begin{array}{llllll}0 & 1 & 2 & 3 & 4 & 5\end{array}$

$\begin{array}{r}\text { Change in community character } \\ \text { Environmental degradation } \\ \hline \text { Crowding/overuse in recreational areas } \\ \hline \text { Income inequality/social inequality } \\ \hline \text { Lack of resources and revenue } \\ \hline \text { Average wages relative to cost of living } \\ \hline \text { Other } \\ \hline \text { Other }\end{array}$


Q19 To what extent does your community have tensions between long-time residents and recent residents?

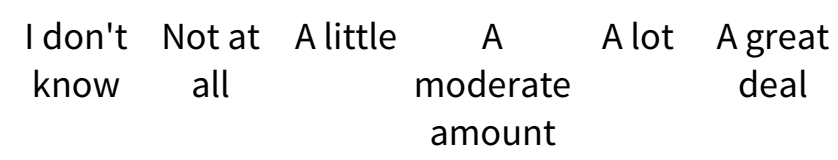

\begin{tabular}{llllllll}
0 & & 1 & 2 & 3 & 4 & 5 \\
\hline & 1 & & & & & &
\end{tabular}

Q20 To what extent does your community have tensions between residents and tourists?

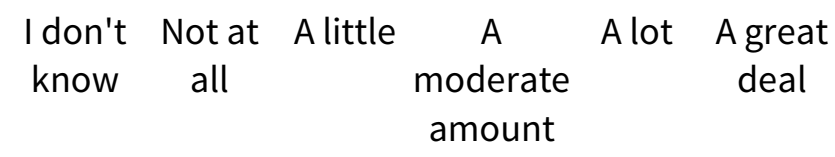

$\begin{array}{llllll}0 & 1 & 2 & 3 & 4 & 5\end{array}$

1 
Q21 Tell us about regional planning in your community.

To what extent are different jurisdictions and entities involved in regional collaborations to How effective have these collaborative efforts been? address the following challenges?

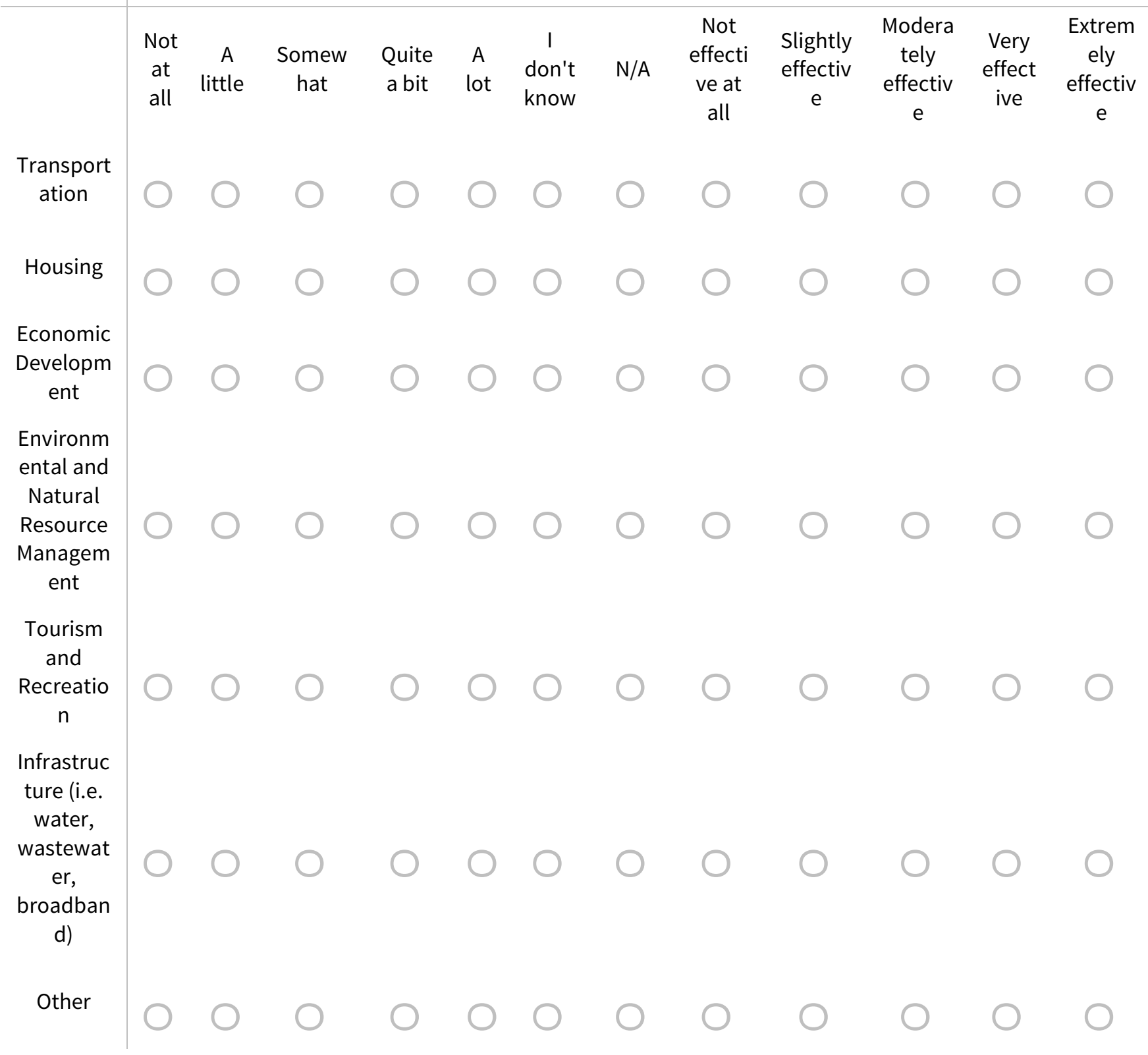

Q22 To what extent does your community ever experiment with temporary solutions to see how effective they are before implementing long-term or permanent solutions? For example, closing a street for a week to demonstrate a possible pedestrian boulevard. 


I don't Never Sometimes Often Most of Always
know
the time

$\begin{array}{lllll}1 & 2 & 3 & 4 & 5\end{array}$

1

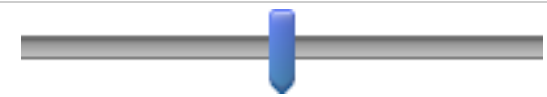

Q23 If yes, what are a few examples of those experimental solutions?

Q24 In general, how easy or hard is it to travel around your community?

Extremely easy

Somewhat easy

Neither easy nor difficult

Somewhat difficult

Extremely difficult

I don't know 
Q25 Which of the following transportation options exist in your community? (select all that apply)

Free public transit

Paid public transit

Bike share programs

E-bike share programs

Protected bike lanes

Sidewalks

Carpool lanes

Paid parking

Free parking

Bike trails/multi-use trails

Other:

Other: 
Q26 How satisfied are residents with the transportation options available in your community?

Extremely satisfied

Somewhat satisfied

Neither satisfied nor dissatisfied

Somewhat dissatisfied

Extremely dissatisfied

I don't know

Q27 How satisfied are tourists with the transportation options available in your community?

Extremely satisfied

Somewhat satisfied

Neither satisfied nor dissatisfied

Somewhat dissatisfied

Extremely dissatisfied

I don't know

Q28 Is there anything you think your community should be doing to improve the quality of transportation in your community?

Q29 Are there any innovative transportation strategies that your community is pursuing, or has implemented that you would like to share? 
Q30 What percentage of housing units in your community are occupied by year-round residents?

$>75 \%$

$50 \%-75 \%$

$25 \%-49 \%$

I don't know

Q31 What is your community doing to provide affordable housing? (select all that apply)

Relaxing land use/zoning regulations

Requiring and administering income-based deed restrictions

Inclusionary zoning (aka fair-share housing or community benefits zoning)

Supporting/utilizing a community land trust

Developing publicly owned land for affordable housing

Offering density bonus incentives

Offering impact fee or other fee/waiver/deferral incentives

Providing rental or ownership subsidies

Permitting tiny homes

Housing affordability is not a challenge in our community

Allowing or encouraging accessory dwelling units

Other

Other

Other 
l don't know

Q32 Do you believe your community is doing enough to address housing challenges?

Definitely yes

Almost enough

Somewhat

Not enough

Definitely not

I don't know

Q33 What tools or resources would help your community address the housing challenges it faces?

Q34 Do you or people in your community aspire to be like other communities? If so, what are those cities or communities? For example, "we want to be like

Q35 Do you or people in your community say "We do not want to be like "? If so, w hat are those cities or communities? 
Q36 Has your community adopted plans for the following? (Select all that apply)

General plan

Affordable housing

Transportation

Economic development

Capital facilities/improvements

Climate change preparedness/adaptation/resilience

Natural disaster/hazard preparedness

Open space/parks plan

Other

I don't know

Q37 On a scale of 1 to 5, how helpful has the American Planning Association and/or your State Chapter of the American Planning Association at providing support to communities like yours?

I don't Not at A little SomewhatModerately Very

know all helpful helpful helpful helpful helpful

$\begin{array}{llllll}0 & 1 & 2 & 3 & 4 & 5\end{array}$

1

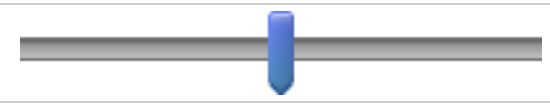


Q38 How helpful would an online toolkit or forum to support planning in gateway, natural amenity, and resort communities be for you and your community?

Very helpful

Helpful

Moderately helpful

A little helpful

Not at all helpful

I don't know

Q39 Are there any other tools or resources you think would help your community? For example, model ordinances, case studies, white papers, etc.

Q40 If you would like to be considered for a prize drawing, please provide your name:

Q41 If you would like to be considered for a prize drawing, please provide your e-mail address:

Q42 Would you be interested and willing to participate in follow-up research on these topics?

\section{Yes}

No 


\section{APPENDIX D}

\section{“OTHER" PROBLEMS REPORTED BY QUESTIONNAIRE RESPONDENTS}

\begin{tabular}{|c|c|c|}
\hline $\begin{array}{l}\text { Accessibility/cost to recreational } \\
\text { areas }\end{array}$ & $\begin{array}{l}\text { Lack of economic } \\
\text { development }\end{array}$ & Resistance to change \\
\hline $\begin{array}{l}\text { Adequate infrastructure for growing } \\
\text { population }\end{array}$ & Lack of economic diversity & Short term rentals \\
\hline Aging infrastructure & Lack of housing & Short-term rental properties \\
\hline Air quality & Lack of housing options & $\begin{array}{l}\text { Sprawl and development just } \\
\text { outside our city border }\end{array}$ \\
\hline Apathy & Lack of law enforcement & $\begin{array}{l}\text { State government removing } \\
\text { local control }\end{array}$ \\
\hline Community engagement & $\begin{array}{l}\text { Lack of natural gas as a } \\
\text { resource }\end{array}$ & Student population growth \\
\hline $\begin{array}{l}\text { Cost of infrastructure to serve a large } \\
\text { seasonal/visitor population }\end{array}$ & Lack of transportation & The good old boys club! \\
\hline Declining infrastructure/assets & Lack of work force & Threat from wildfires \\
\hline Drug use & Local control over land use & Too many events \\
\hline Economically depressed area & Loss of mineral tax & $\begin{array}{l}\text { Unfunded mandates by state } \\
\text { or federal regulations }\end{array}$ \\
\hline Equity of green space/urban canopy & Loss of severance tax & Un-kept properties \\
\hline $\begin{array}{l}\text { Excessive increase in need for } \\
\text { recycling volume and solid waste }\end{array}$ & Loss of young population & $\begin{array}{l}\text { Vacant buildings/retail } \\
\text { trends }\end{array}$ \\
\hline $\begin{array}{l}\text { Finding water sources to } \\
\text { accommodate growth }\end{array}$ & Maintenance vs funding & Vacation rental boom \\
\hline Funding for school facilities & $\begin{array}{l}\text { Migrant \& year-round } \\
\text { homeless populations }\end{array}$ & War on coal \\
\hline General lack of broadband & $\begin{array}{l}\text { Money for infrastructure } \\
\text { projects }\end{array}$ & $\begin{array}{l}\text { Waste management } \\
\text { problems }\end{array}$ \\
\hline
\end{tabular}




\begin{tabular}{|l|l|l|}
\hline High cost of health care/insurance & More jobs than workforce & $\begin{array}{l}\text { Water availability and } \\
\text { conservation }\end{array}$ \\
\hline Homeless population & No housing & $\begin{array}{l}\text { Water sources to meet new } \\
\text { growth }\end{array}$ \\
\hline Homelessness & $\begin{array}{l}\text { Not appealing to younger } \\
\text { generations }\end{array}$ & Wildfires \\
\hline Housing availability nor affordability & $\begin{array}{l}\text { Not having enough suitable } \\
\text { housing }\end{array}$ & Winter activities \\
\hline Housing stock & $\begin{array}{l}\text { Not having enough viable } \\
\text { businesses }\end{array}$ & Workforce availability \\
\hline Inadequate housing for workforce & Old infrastructure & $\begin{array}{l}\text { Worsening local control due } \\
\text { to state restrictions }\end{array}$ \\
\hline Increase in second homes & $\begin{array}{l}\text { Operating costs increasing } \\
\text { greater than revenue sources }\end{array}$ & Year round economy \\
\hline Lncrease in forest fires/smoke & $\begin{array}{l}\text { Permanent "good" jobs few } \\
\text { and far between }\end{array}$ & $\begin{array}{l}\text { Quality of public school } \\
\text { system }\end{array}$ \\
\hline Labor Shortages & Political will & \\
\hline Lack of available housing & livable wage. & \\
\hline Lack of & & \\
\hline
\end{tabular}




\section{Below is a word cloud of those results}

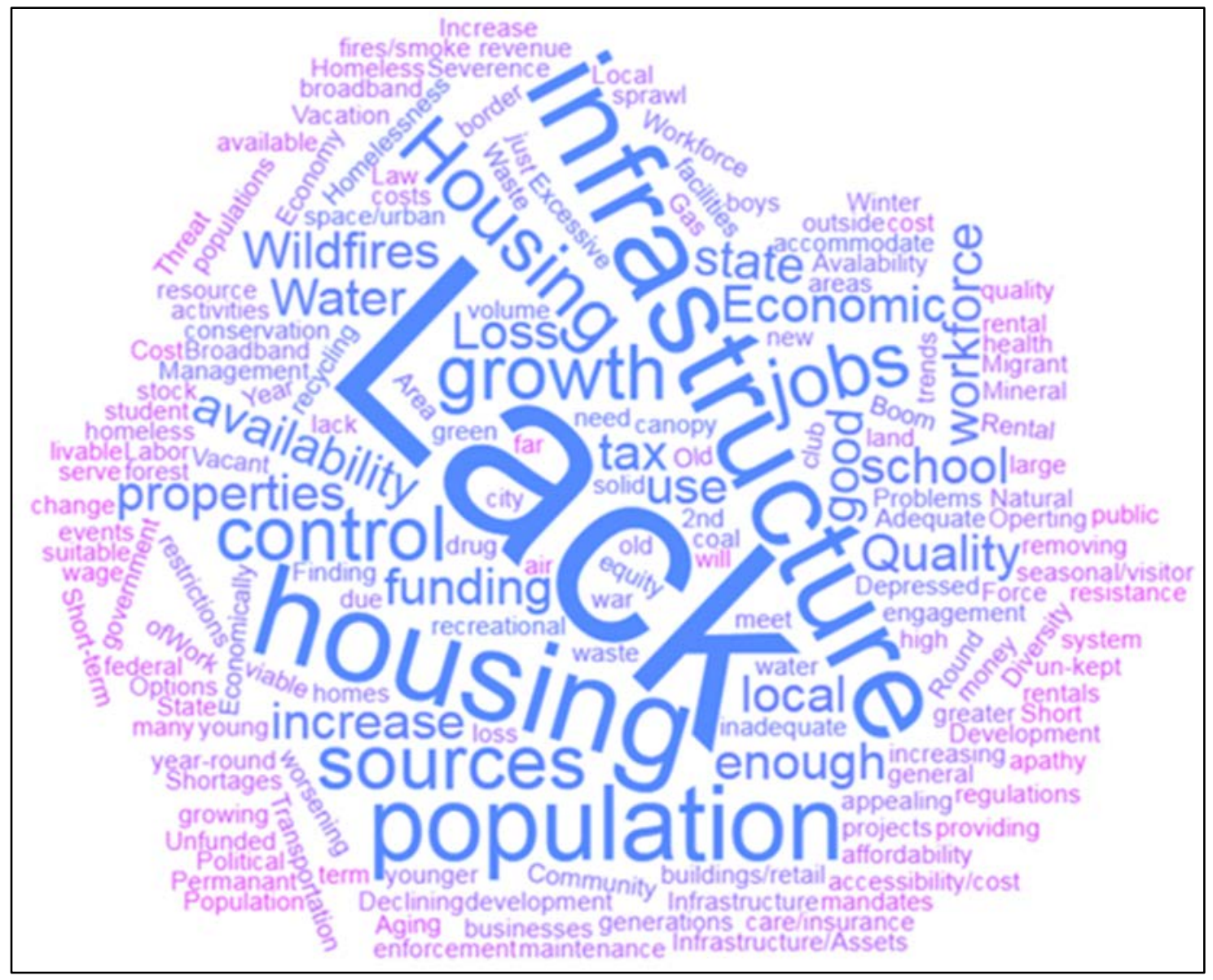

